\title{
Lobster shal: Comparison with Drosophila shal and Native Potassium Currents in Identified Neurons
}

\author{
Deborah J. Baro, Lisa M. Coniglio, Cathy L. Cole, Hilda E. Rodriguez, Julie K. Lubell, Marshall T. Kim, and \\ Ronald M. Harris-Warrick
}

Section of Neurobiology and Behavior, Cornell University, Ithaca, New York 14853

The transient potassium $\left(\mathrm{K}^{+}\right)$current, or A-current $\left(\mathrm{I}_{\mathrm{A}}\right)$, plays an essential role in shaping the firing properties of identified neurons in the 14-cell pyloric network in the stomatogastric ganglion of the spiny lobster, Panulirus interruptus. The different cells in the pyloric network have distinct $\mathrm{I}_{A} \mathrm{~s}$. To begin to understand the molecular basis for $I_{\wedge}$ heterogeneity, we examined the relationship between the Panulirus shal current, the $I_{A} s$ in the lateral pyloric (LP) and pyloric dilator (PY) cells, and the Drosophila shal current. After isolating a complete open reading frame for lobster shal 1, which shows significant sequence homology to the fly, mouse, and rat shal homologs, we used a single-cell reverse transcription polymerase chain reaction method to demonstrate that the shal 1 gene was expressed in the LP and PY cells. Next, we compared the lobster shal 1

The pyloric central pattern generator in the crustacean stomatogastric ganglion is one of the best understood neural networks (Selverston and Moulins, 1987; Harris-Warrick et al., 1992). This 14-neuron network is composed of six major cell types. Each cell type has a unique electrophysiological phenotype, with marked differences in plateau, bursting, and postinhibitory rebound properties (Hartline and Graubard, 1992). We are exploring the roles of identified ionic currents in configuring the electrophysiological properties of pyloric neurons, and thereby shaping the motor pattern generated by the network.

The fast transient potassium $\left(\mathrm{K}^{+}\right)$current, or A-current $\left(\mathrm{I}_{\mathrm{A}}\right)$, is instrumental in creating the pyloric motor pattern. The $\mathrm{I}_{\mathrm{A}}$ plays a role in determining the overall cycle frequency of the pyloric rhythm and influences the intensity of cell activity and the phasing of pyloric neurons in the motor pattern (Tierney and HarrisWarrick, 1992). Moreover, one mechanism by which the monoamine dopamine alters the motor pattern is by differentially modulating the $\mathrm{I}_{\mathrm{A}} \mathrm{s}$ in specific cells (Harris-Warrick et al., 1995a,b).

Five of the six cell types in the pyloric network have a detectable $I_{A}$ as measured by two-electrode voltage clamp from the cell soma (Tierney and Harris-Warrick, 1992). The somatic $\mathrm{I}_{\mathrm{A}} \mathrm{s}$ in these five

\footnotetext{
Received Sept. 27, 1995; revised Dec. 14, 1995; accepted Dec. 15, 1995.

This work was funded by National Institutes of Health Grants NS25915 and NS17323 and a grant from the Human Frontiers Science Program to R.H.-W., as well as a Hughes undergraduate fellowship to H.E.R. We thank Thomas Podleski for his continued advice and support as well as a critical reading of this manuscript. We also thank David McCobb, Linda Nowak, Robert Levini, Bruce Johnson, Lauren French, and Jack Peck for their comments on the manuscript. We thank Allen Selverston for the three Stratagene cDNA libraries and Aguan Wei and Lawrence Salkoff for the Drosophila shal 2 clone.

Correspondence should be addressed to Deborah J. Baro, Section for Neurobiology and Behavior, Cornell University, Seeley G. Mudd Hall, Ithaca, NY 14853.

Copyright $\odot 1996$ Society for Neuroscience $0270-6474 / 96 / 161689-13 \$ 05.00 / 0$
}

current generated in a Xenopus oocyte expression system to the $\mathrm{I}_{A} \mathrm{~s}$ in the LP and PY neurons as well as to the Drosophila shal current in Xenopus oocytes. While the transient $\mathrm{K}^{+}$lobster shal 1 current was similar to the $I_{A} s$ in pyloric neurons, a detailed comparison shows that they are not identical and differ in kinetic and voltage-dependent parameters. The highly homologous lobster and fly shal genes also produce currents with some significant similarities and differences in an oocyte expression system.

Key words: A-current; stomatogastric ganglion; oocyte expression; single-cell reverse transcription polymerase chain reaction method; identified neuron; central pattern generator; Shaker family

different cell types are distinct, and these distinctions are essential for the generation of the motor pattern (Graubard and Harlline, 1991; Golowasch and Marder, 1992; Golowasch et al., 1992; Hartline and Graubard, 1992; Tierney and Harris-Warrick, 1992; Hartline et al., 1993; Harris-Warrick et al., 1995a,b). This is exemplified in a comparison of the lateral pyloric (LP) and pyloric constrictor (PY) cells.

The somatic $I_{A} s$ in the LP and PY cells differ in their voltage activation curves (Harris-Warrick et al., 1995a,b). The activation curve for the LP is shifted in the depolarizing direction relative to that of the PY. As a result, the LP $\mathrm{I}_{\mathrm{A}}$ is smaller than the PY $\mathrm{I}_{\mathrm{A}}$ at any submaximal activating voltage. This difference has functional consequences for the generation of the pyloric motor pattern such that the LP cell fires before the PY cells in the pyloric rhythm. During the pyloric motor pattern, the LP and PY neurons are rhythmically inhibited by a set of oscillatory pacemaker neurons. When the LP and PY neurons are simultaneously released from this synaptic inhibition, both cells exhibit postinhibitory rebound and begin to repolarize, but the LP cell repolarizes faster than the PY cells and fires first, partly because it has a smaller $I_{A}$ than the PY cells (Hartline, 1979; Golowasch and Marder, 1992; Tierney and Harris-Warrick, 1992; Harris-Warrick et al., 1995a,b).

We are exploring the molecular basis for $I_{A}$ heterogeneity in pyloric neurons. As a first step, we are trying to determine which Shaker family genes underlie the $\mathrm{I}_{\mathrm{A}} \mathrm{s}$ in pyloric neurons. In Drosophila, electrophysiological analyses of Shaker family mutants have defined which genes underlie the $\mathrm{I}_{\mathrm{A}} \mathrm{s}$ in a variety of cell types. The shaker current is the major component of the $\mathrm{I}_{\mathrm{A}}$ in Drosophila photoreceptor and muscle cells (Salkoff and Wyman, 1981; Wu and Haugland, 1985; Elkins and Ganetzky, 1988; Zagotta et al., 1988; Singh and $\mathrm{Wu}_{\mathrm{u}}$ 1989; Haugland and $\mathrm{Wu}, 1990$; Hardie et al., 1991). Shaker also contributes to neuronal $\mathrm{I}_{\mathrm{A}} \mathrm{s}$, but most studies 
Figure 1. Diagrammatic representation of the Panulirus shal transcript and clones. The bar represents the Panulinus shal transcript. The shaded portions represent the $5^{\prime}$ and $3^{\prime}$ untranslated regions, and the open portion represents the protein-coding region. The arrows at the ends of the bar indicate that the transcript extends for an unknown distance in either direction. The striped regions within the protein-coding region represent the approximate positions of the six putative membrane-spanning regions. The core region is demarcated by asterisks. The transcript is numbered such that the first $\mathrm{A}$ in the coding region is ${ }^{+} 1$. Relevant restriction sites are shown above the transcript $(K=K p n \mathrm{I} ; X=$ XhoI; $S=S a c \mathrm{I}$ ). The numbered boxes represent the eight shal-specific primers described in the text. The arrow above each box indicates the direction in which the prinner is extended. The seven shal clones described in the text are aligned underneath the transcript 'The portion of the shal transcript contained within each clone is represented by a line, whereas the boxes on either end represent the phage arms. The positions of the relevant restriction sites and promoter in the vector are indicated.

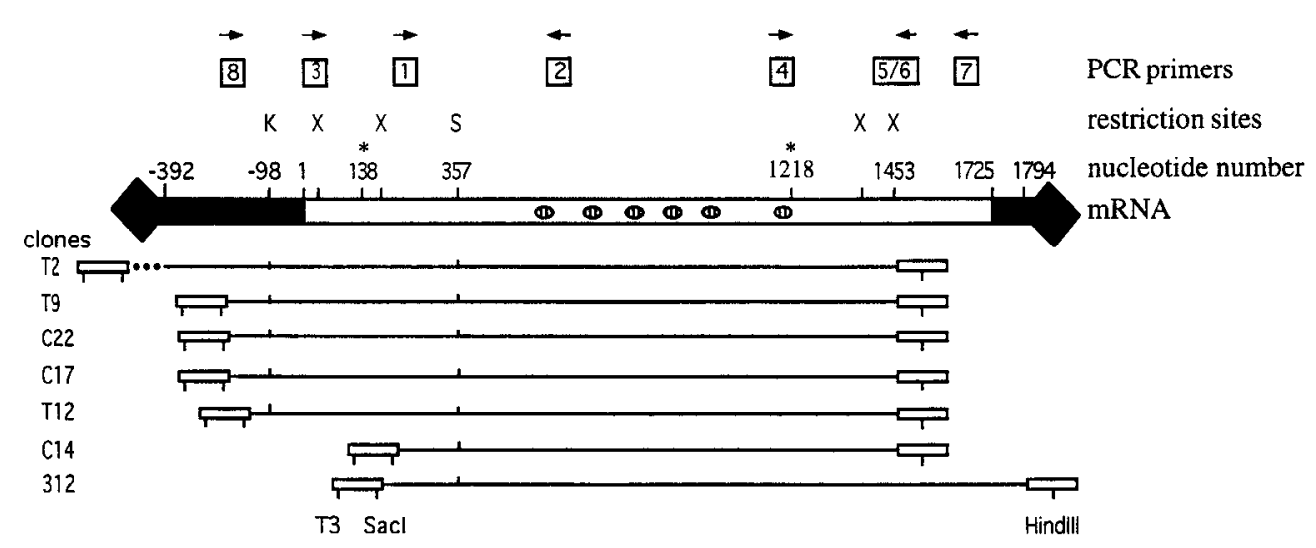

indicate that it is not the major component of these currents (Jan et al., 1977; Tanoyue et al., 1981; Solc et al., 1987; Solc and Aldrich, 1988; Baker and Salkof, 1990; Schwartz et al., 1990; Tsunoda and Salkoff, 1995a,b). Furthermore, studies on cultured embryonic neurons derived from shal mutants indicate that the shal current is the major constituent of embryonic neuronal $\mathrm{I}_{\mathrm{A}} \mathrm{s}$ (Tsunoda and Salkoff, 1995a).

We have examined Shaker family gene expression in individual stomatogastric neurons using a single-cell reverse transcription polymerase chain reaction (RT-PCR) method (Baro et al., unpublished data). At least $72 \%$ of stomatogastric neurons express all four Shaker family genes, with 100 and $94 \%$ of these neurons expressing the Shaker and shal genes, respectively. Therefore, although it is possible that one gene can encode the somatic $\mathrm{I}_{\mathrm{A}}$ in a stomatogastric neuron, it is also likely that a combination of Shaker family genes encodes this current.

To address this issue, we cloned the complete open-reading frame (ORF) of a shal cDNA molecule from the spiny lobster, Panulirus interruptus, and expressed the cRNA in oocytes. We used single-cell RT-PCR to demonstrate that the shal 1 gene is expressed in the LP and PY cells. We then compared the $I_{A} s$ in the LP and PY cells with the shal current obtained in an oocyte expression system. Finally, to examine whether the evolutionary conservation of the gene resulted in functional conservation of the current, we compared lobster and fly shal currents obtained under identical conditions.

Some of these data have been reported previously in abstract form (Baro et al., 1994b).

\section{MATERIALS AND METHODS}

\section{Oligonucleotide primers}

The Panulinus shal-specific polymerase chain reaction (PCR) primers are as follows:
(1) 5' -TCCAACGAGAGAGAATTCTTCTACGATGAAGAAACAAAAGAG-3' (205-246)

(2) 5'-CACCGTCTCTACCACATTGGCCATCAC-3' (595-621)

(3) 5'-ATGGCCTCGGTGGCCGCTTGGTT-3' (1-23)

(4) 5'-ATTGTGGGTGGCGTGTGTTCGCTATCC-3' (1153-1179)

(5) 5'-TTCTCGAGGCAACGGAGTAGATGGTGATGC-3' (1431-1460)

(6) 5'-TGGTCTTCTCGAGGC-3' (1451-1465)

(7) 5'-GAGAAAGACAGGTCTACC-3' (1641-1658)

(8) 5'TCTGCCCTGCTTGCG3' ( -223 to -209$)$

The positions of these primers within the shal cDNA and the directions in which they are extended are indicated in Figure 1. The numbers after each primer indicate its position in Figure 2.

\section{$R N A$ and genomic DNA isolation}

Total RNA was isolated according to Chomczynski and Sacchi (1987). $\Lambda$ magnasphere kit (Promega, Madison, WI) was used to isolate mRNA from total RNA. Genomic DNA was isolated from tail muscle (Ausubel el al., 1990).

\section{Construction of a cDNA library}

Methylmercuric hydroxide-treated mRNA (Payvar and Schimke, 1979) isolated from brain, abdominal, and thoracic ganglia was reversed transcribed using random hexamers and oligo-dT as primers and a Stratagene cDNA synthesis kit (La Jolla, CA). Second-strand synthesis, addition and phosphorylation of $E c o$ RI adapters, and size selection were as described in the kit. The EcoRI-adapted cDNA was nondirectionally cloned into the EcoRI site of Lambda ZapII, packaged, and used to infect XL1-Blue cells using a Stratagene Predigested Lambda ZapIL/EcoRI Cloning Kit and Gigapack Gold packaging extracts. The complexity of the library is $10^{7} \mathrm{pfu}$, and the average insert size is $1.7 \mathrm{~kb}$. The library was amplified once.

\section{PCR screening of cDNA libraries}

Phage were plated at a density of $5 \times 10^{4}$ pfu per plate and incubated at $37^{\circ} \mathrm{C}$ until confluent. The plates were then overlaid with $10 \mathrm{ml}$ of SM buffer (Sambrook et al., 1989), and the phage diffused into the buffer at $4^{\circ} \mathrm{C}$ overnight with gentle shaking. The lysate $\left(\sim 5 \times 10^{9} \mathrm{pfu} / \mathrm{ml}\right)$ from each plate was collected and $1 \mathrm{ml}$ of the lysate from each of six plates was 
combined. Chloroform was added to $1.0 \%$ and the lysates were stored at $4^{\circ} \mathrm{C}$. The combined lysates were screened with primers from several different genes over the course of 1 year. In the shal screen, $5 \mu l$ of the combined lysate served as the template in the following PCR (per tube): $0.2 \mathrm{mM}$ of each deoxynucleoside triphosphate, $2.5 \mathrm{mM} \mathrm{MgCl}_{2}, 2.5 \mathrm{U} \mathrm{Taq}$ DNA polymerase, $10 \mu \mathrm{l}$ of $10 \times$ PCR buffer supplied with the enzyme, 25 pmol each of shal-specific primers 1 and 2 , and $\mathrm{H}_{2} \mathrm{O}$ to $100 \mu \mathrm{l}$. All reaction components were assembled except the template and the Taq DNA polymerase, and heated to $80^{\circ} \mathrm{C}$, at which point the DNA polymerase was added. Ninety five microliters of the mix was aliquoted into tubes containing mineral oil at $80^{\circ} \mathrm{C}$, and $5 \mu \mathrm{l}$ of a combined lysate was added to each tube. The reaction was heated for $5 \mathrm{~min}$ at $95^{\circ} \mathrm{C}$ to disrupt the phage coat and denature the DNA. The reaction then cycled as follows: $30 \times: 94^{\circ} \mathrm{C}, 1^{\prime} \rightarrow 64^{\circ} \mathrm{C}, 1^{\prime} \rightarrow 72^{\circ} \mathrm{C}, 1^{\prime} ; 10 \times: 94^{\circ} \mathrm{C}, 1.5^{\prime} \rightarrow 64^{\circ} \mathrm{C}$, $1^{\prime} \rightarrow 72^{\circ} \mathrm{C}, 1^{\prime}+10^{\prime \prime}$ extension per cycle. Ten microliters of the completed PCK was run on an agarose gel. If a 417 base pair (bp) band, representing shal nucleotides 205-621, was observed after ethidium bromide staining, the combined lysate was considered positive, and the six original lysates that made up the combined lysate were individually screened in a PCR. The positive clone was isolated from the lysate using conventional techniques (see below).

\section{Conventional screening of plaques}

Lambda plaques were screened with a primer-extended DNA probe as described in Ausubel et al. (1990). The DNA probe used to screen the plaques was a gel-isolated (Glass-pac, National Scientific, San Diego, CA) 417 bp shal-specific fragment, generated in a PCR as described above using the cloned Panulinus shal core as the template (Baro et al., 1994a). The probe was labeled with ${ }^{32} \mathrm{P}$ in a primer extension reaction (Ausubel et al., 1990) using the shal-specific primers 1 and 2.

\section{Sequencing}

Plasmids were rescued from positive phage using R408 helper phage in an in vivo excision protocol provided by Stratagene. Plasmids were sequenced using the nested deletion method (Henikoff, 1987) and shalspecific oligonucleotide primers (not shown). Sequencing reactions were performed with a Sequenase kit (United States Biochemical, Cleveland, $\mathrm{OH}$ ) and resolved on 6\% denaturing polyacrylamide (Sambrook et al., 1989) wedge (International Biotechnologies, New Haven, CT) gels.

\section{Dissection, cell identification}

Pacific spiny lobsters (Panulinus interruptus) were purchased from Don and Laurice Tomlinson in San Diego and maintained in marine aquaria at $15^{\circ} \mathrm{C}$. The stomatogastric nervous system was dissected (Mulloney and Selverston, 1974) and pinned in a dish. The pyloric neurons were identified electrophysiologically by (1) the presence of simultaneous spikes recorded intracellularly in the soma and extracellularly in nerve branches innervating identified muscles; (2) the characteristic shape of the bursts; and (3) the timing of activity in the pyloric rhythm (Flamm and HarrisWarrick, 1986).

\section{Single-cell RT-PCR}

Pyloric neurons were identified and isolated for single-cell RT-PCRs. Single-cell RT-PCRs were performed exactly as described in Baro et al. (unpublished data) using shal-specific primers 4, 5, and 6. Preprints are available on request.

\section{Construction of a Panulirus shal clone with a complete ORF}

Clone K/S10, which contains the complete ORF of the Panulirus shal 1 gene, was constructed in the following manner. Plasmids were rescued from clones $\mathrm{C} 22$ and $3-12$ (Fig. 1) as described above. The $0.454 \mathrm{~kb}$, gel-isolated $\mathrm{KpnI} / \mathrm{SaCI}$ fragment from the $\mathrm{C} 22$ plasmid was ligated to a 4.4 $\mathrm{kb}$ (3 kb Bluescript vector $+1.4 \mathrm{~kb}$ insert), phosphatased (Sambrook et al., 1989)-, gel-isolated-SacI fragment from the 3-12 plasmid in the following $5 \mu \mathrm{l}$ reaction: $0.025 \mathrm{pmol} 3-12$ fragment, 0.075 pmol $\mathrm{C}_{2} 2$ fragment, $30 \mathrm{~mm}$ Tris, $\mathrm{pH} 7.8,10 \mathrm{mM} \mathrm{MgCl}_{2}, 10 \mathrm{~mm}$ dithiothreitol, $1 \mathrm{~mm}$ ATP, and $1.5 \mathrm{U}$ ligase. The ligation reaction was incubated at $16^{\circ} \mathrm{C}$ overnight. One microliter of the ligation reaction was used directly to transform $100 \mu \mathrm{l}$ of frozen competent (Hanahan, 1983) XL1-Blue cells (Stratagene); colonies were selected on ampicillin platcs. Twenty random colonies were individually picked into NZY broth (Sambrook et al., 1989) and grown at $37^{\circ} \mathrm{C}$ overnight. Overnight cultures were screened for the correct ligation product using $1 \mu \mathrm{l}$ of the overnight culture as a template in a standard PCR containing shal-specific primers 3 and 7 at an anneal- ing temperature of $53^{\circ} \mathrm{C}$. One colony containing the correct product was sequenced across the ligation sites using T3, shal-specific 1 , and shalspecific 2 as the sequencing primers. Restriction digests confirmed that unwanted rearrangements did not occur.

\section{Xenopus oocyte expression}

Shal DNA clones K/S10 (Panulinus) and Shal 2 (Drosophila) (Wei et al., 1990) were linearized with HindIII (Panulirus) or EcoRI (Drosophila) in a standard restriction digest (Sambrook et al., 1989) and used as templates in transcription reactions. Capped transcripts werc madc with a Stratagene mCap kit using T3 RNA polymerase according to the instructions provided. The completed DNased transcription reactions were phenol/ $\mathrm{CHCl}_{3}$ extracted, ETOH-precipitated, and resuspended in sterile distilled $\mathrm{H}_{2} \mathrm{O}$ at a concentration of $\sim 100 \mathrm{ng} / \mu \mathrm{l}$. A Sutter Instrument microinjecter (San Rafael, CA) was used to inject $\sim 100 \mathrm{nl}$ of the cRNA into Xenopus oocytes, which were isolated and maintained according to Quick et al. (1992).

\section{Voltage-clamp recordings}

Xenopus oocytes. A standard two-microelectrode voltage clamp was used to study the activation and inactivation properties of the lobster and fly shal currents. Oocytes were held at $-50 \mathrm{mV}$. The shal current was elicited by a hyperpolarizing prepulse to remove resting inactivation followed by a depolarizing test pulse. Xenopus oocytes have endogenous currents (ranging from approximately -100 to $+500 \mathrm{nA}$ ) that are evoked by this voltage paradigm. Although this did not pose a problem for the lobster shal current, which was typically $10-15 \mu \mathrm{A}$, it did introduce some error into our measurements of the smaller Drosophila shal current, which was typically about $1-2 \mu \mathrm{A}$. To control for these endogenous currents, current traces from at least $10 \mathrm{H}_{2} \mathrm{O}$-injected oocytes (from the same frog as the cRNA-injected oocytes), elicited in response to the voltage paradigm used, were recorded, and the average was subtracted from the lobster and fly shal currents before analysis. This was done for all experiments. All recordings were done with an Axoclamp 2A amplifier (Axon Instruments, Foster City, CA) controlled by an Everex Step-386 computer equipped with pClamp software (Axon Instruments). The current signal was filtered at $500 \mathrm{~Hz}$, and the time invariant leak current was subtracted. Both current and voltage traces were digitized and stored on disk. Electrode resistances ranged from 0.2 to $1.0 \mathrm{M} \Omega$. The electrode solution was $3 \mathrm{M}$ $\mathrm{KCl}$. The oocytes were continuously perfused in ND96 (in mM): $96 \mathrm{NaCl}$, $2 \mathrm{KCl}, 1.8 \mathrm{CaCl}_{2}, 1 \mathrm{MgCl}_{2}, 5 \mathrm{HEPES}$, pH 7.6 , at $16^{\circ} \mathrm{C}$. All drugs were dissolved in ND96. Increased levels of $\mathrm{K}^{+}$in the saline were compensated for by a decrease in external sodium concentration.

Panulirus neurons. Recordings were made as described previously (Harris-Warrick et al., 1995a,b). Briefly, neurons were voltage clamped in lobster saline containing $10^{-7} \mathrm{M}$ tetrodotoxin, $20 \mathrm{mM}$ tetraethylammonium (TEA), $200 \mu \mathrm{M} \mathrm{CdCl}$, and $5 \times 10^{-6} \mathrm{M}$ picrotoxin to greatly reduce non- $\mathrm{I}_{\mathrm{A}}$ currents and synaptic inputs. To further remove non- $\mathrm{I}_{\mathrm{A}}$ currents, a series of voltage sleps from a loolding potential of $-50 \mathrm{mV}$ (in which $\mathrm{I}_{\mathrm{A}}$ is largely inactivated) was digitally subtracted from a series of voltage steps with a $200 \mathrm{msec}$ prestep to $-100 \mathrm{mV}$ (to remove resting inactivation). The remaining current could be abolished by the $\mathrm{I}_{\mathrm{A}}$-selective channel blocker 4-aminopyridine.

Voltage-clamp paradigms and curve fitting. To obtain the inactivation time constants, the decay of 10 averaged current traces elicited from a cell by a $-90 \mathrm{mV}$ (oocyte) or $-100 \mathrm{mV}$ (neuron) prepulse, followed by a test pulse to $+20 \mathrm{mV}$, was fit with two exponentials using the pClamp least-squares minimization procedure. The minimum number of exponentials required for an adequate fit of the current was two, and the fit was not significantly improved when more than two exponentials were used. The current as a function of time $(t)$ corresponds to the equation:

$$
I=I_{\mathrm{o}}+I_{\mathrm{f}} e^{t / \tau_{\mathrm{f}}}+I_{\mathrm{s}} e^{t / \mathrm{s}_{\mathrm{s}}}
$$

where $\tau_{\mathrm{f}}$ and $\tau_{\mathrm{s}}$ represent the time constants of inactivation and the amplitude of each time constant, and $I_{\mathrm{f}}$ and $I_{\mathrm{s}}$ represent the relative contribution of each component to the peak. Because the purpose of the hyperpolarizing prepulse is simply to remove resting inactivation, a change in the voltage of the hyperpolarizing prepulse will only effect the size of the current we measure and not the rate of decay. Thus, we are able to compare the results obtained using different prepulse potentials for neurons and oocytes.

To obtain the activation curve, currents were evoked by a $-90 \mathrm{mV}$ (oocyte) or $-100 \mathrm{mV}$ (neuron) prepulse to remove inactivation, followed by a test pulse ranging from $-70 \mathrm{mV}$ to $+40 \mathrm{mV}$ (oocyte) or $-50 \mathrm{mV}$ to 


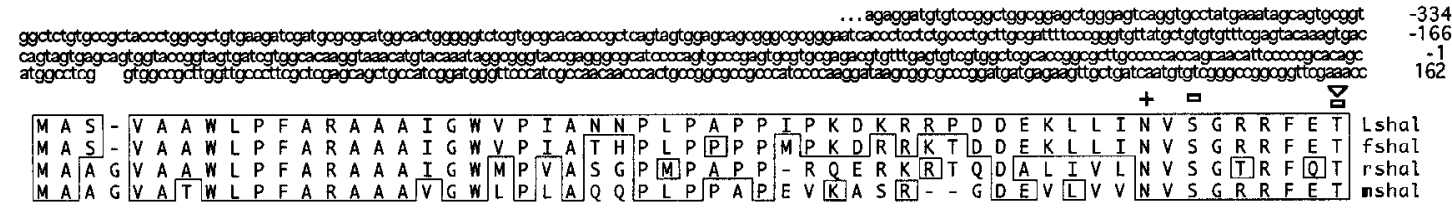

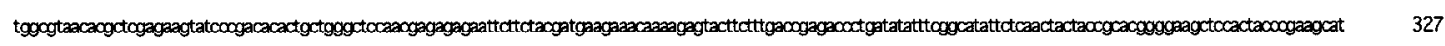
55 WRNTLEKYPDTLLGSNEREFFYDEETKEYFFDRDPDIFRHILNYYRTGKLHYPKH LShal

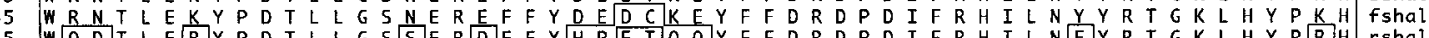

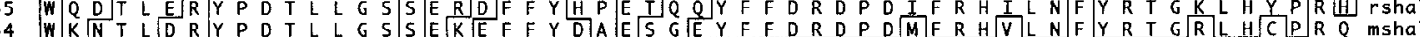

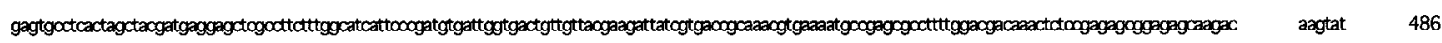
$\circ 0_{0}$ $\infty \quad \infty$

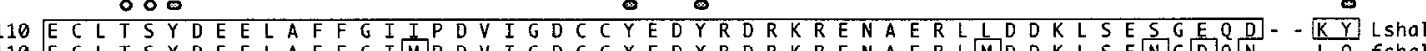
110 E C L T S S Y D E E L A F F G I M P D V I G D C C Y E D Y R D R K R E N A E R L M D D K L S E N G D Q N - - L Q FShal

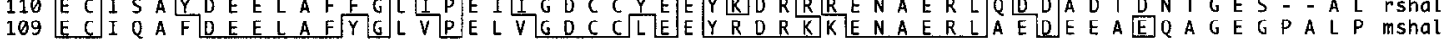

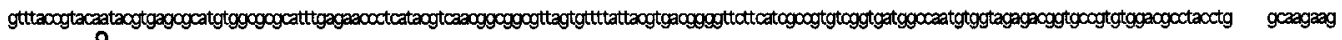
648 163 YYRTIRDGMWRAFEN PHTS TAALVFYYVTGFFIAVSVMANVVETVPCGRLPG - KK LShal

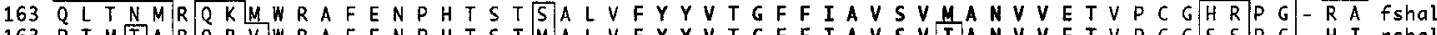

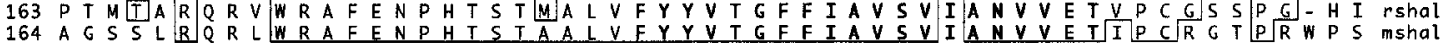

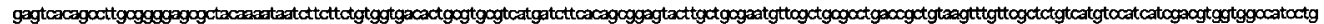

217 [ESQPCGERYKIIFFCGDTACVMIFTAEYLLRMFAAPDRCKFVRSVMSIIDVVAIL LShal 217 G T L P C G E R Y K IV F F C L D T A C V M I F TAAE Y L L R L FAA A P D R C K F F V R S V M S I I D V V A I M FShal 217 K E L L P C G E R Y Y A V A F F C L D T A C V M I F T T V E Y L L R L A A A P S S R Y

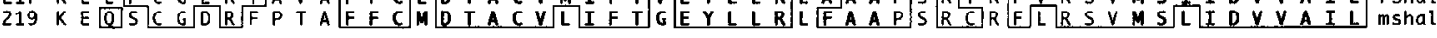

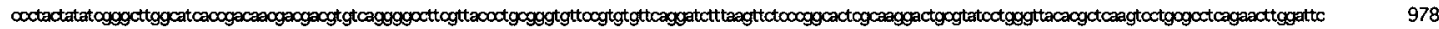

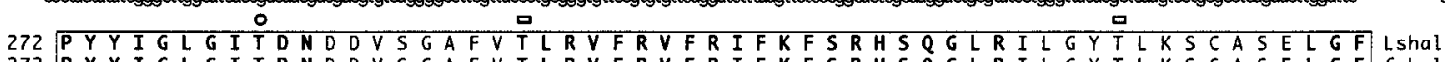

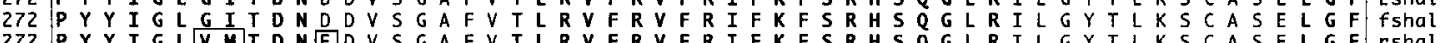

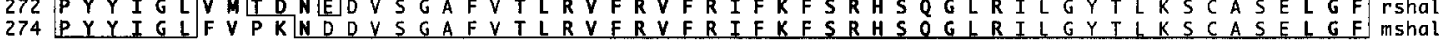

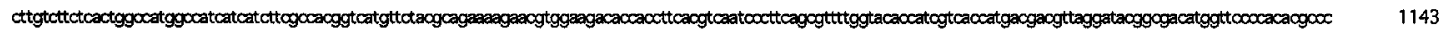

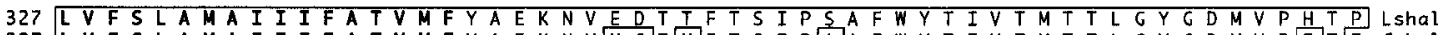
327 L V F S LAMA I I I F A T V M F Y A E K N V N G T N F T S I P A A A F W Y T I I V T M T T L G Y G D M V P E T I Fshal

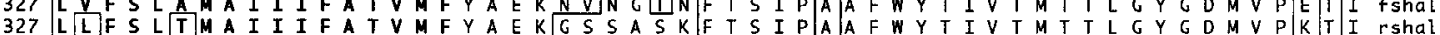

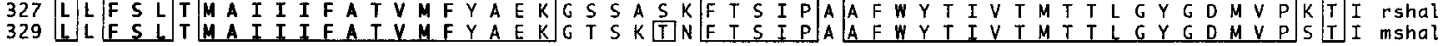

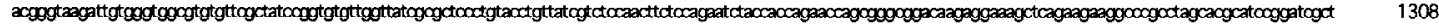

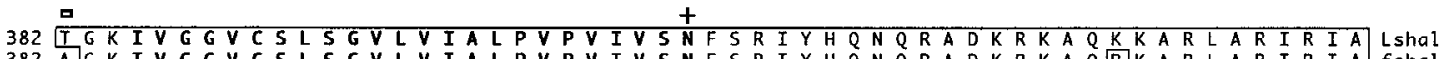

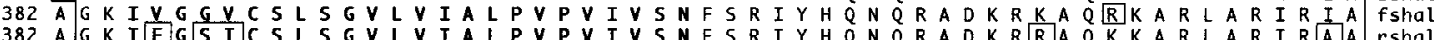

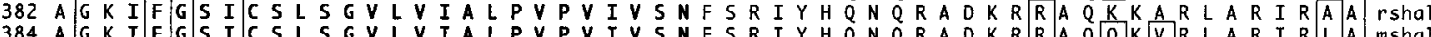

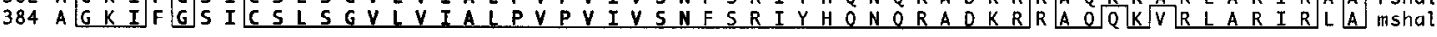

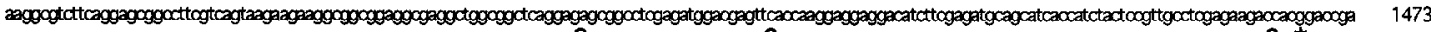
437 KA S SGA AFVSKKKAAEARLAA QESGLEMDEFTKEEDIFEMQHHHLLRCLEKT TDR LShal

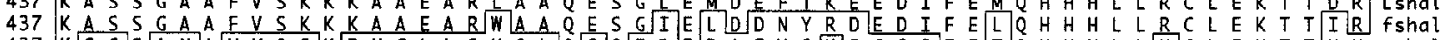

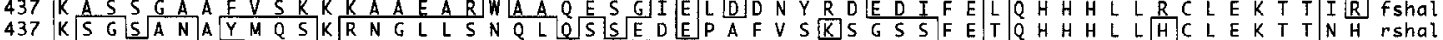

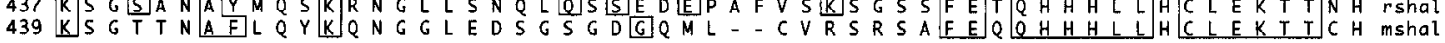

grattogtggagctggaggtgocgtacaatg ggcagocgaatogtocgggcagogogtcocogcoocagagoogaagoccatogcttocagocacactaacttcacogtcact tgctgcggocga

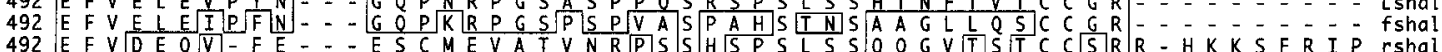

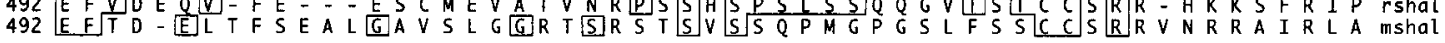

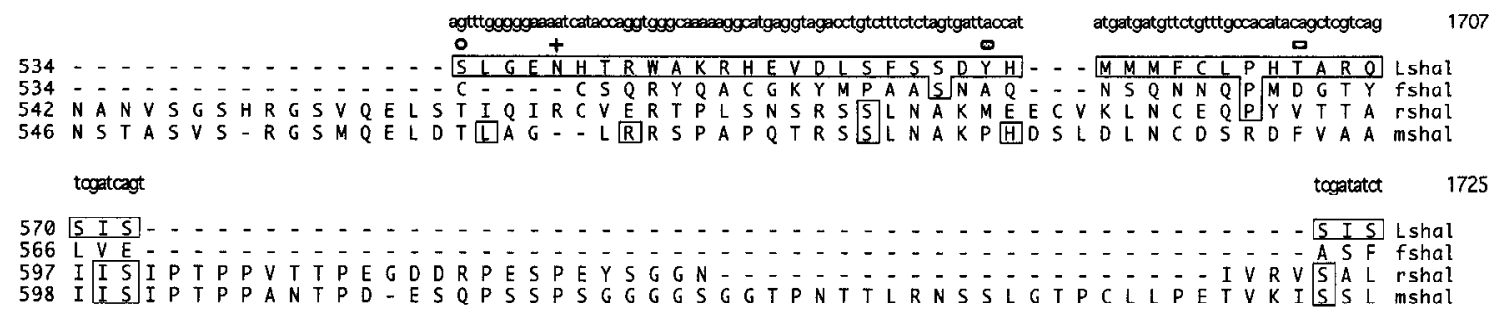


$+20 \mathrm{mV}$ (neuron) in $10 \mathrm{mV}$ increments. Peak current was converted to conductance using a reversal potential of $-94 \mathrm{mV}$ (oocyte) or $-86 \mathrm{mV}$ (neuron). Normalized peak conductances for all cells were averaged and plotted against test-pulse voltages. The activation curve was obtained by fitting the data points to the following Boltzmann equation:

$$
g_{\left(V_{m}\right)}-\bar{g}\left(1 /\left(1+e^{-\left(V_{1 / 2}-V_{m} / a\right)^{n}}\right),\right.
$$

where $g_{(V m)}$ is the peak conductance at a given voltage, $\bar{g}$ is the maximal conductance, $V_{1 / 2}$ is the voltage at which a single gating particle has a $50 \%$ open probability, $V m$ is the test potential, $a$ is the e-fold slope factor, and $n=3 . G_{\max }, V_{1 / 2}$, and $a$ were allowed to vary to obtain the best fit using DeltaPro (Macintosh).

To obtain the inactivation curve, currents were elicited by a $10 \mathrm{sec}$ (oocyte) or $200 \mathrm{msec}$ (neuron) hyperpolarizing prepulse ranging from $-110 \mathrm{mV}$ to $-40 \mathrm{mV}$ (oocyte) or $-100 \mathrm{mV}$ to $-10 \mathrm{mV}$ (neuron), followed by a depolarizing test pulse to $+20 \mathrm{mV}$. The rate of deinactivation is much slower in the oocyte than in the neuron, so the length of the hyperpolarizing prepulse differed for the two protocols. We hyperpolarized the cells until the current was completely deinactivated (e.g., 10 $\mathrm{sec}$ in oocyctes, $200 \mathrm{msec}$ in neurons). Normalized peak currents were averaged and plotted against the prepulse voltage. The inactivation curve was obtained by fitting the data points to Equation 2, where $n=1$.

To obtain the reversal potential, $\mathrm{I}_{\mathrm{A}} \mathrm{s}$ were deinactivated by a prepulse to $-90 \mathrm{mV}$ and activated by a test pulse to $+40 \mathrm{mV}$. Tail currents were then recorded during repolarizing steps to potentials between -20 and -70 in $5 \mathrm{mV}$ increments. Tail current traces were fitted by single exponentials after the clamp had stabilized $(6 \mathrm{msec}$ after the beginning of the repolarizing pulse). Instantaneous current values were estimated by extrapolating back to the initiation of the repolarizing pulse. Instantaneous current values were normalized against the maximum current.

\section{Statistical tests}

All data are given as mean \pm SEM. Differences were identified with an unpaired $t$ test (StatView, Macintosh). A difference was considered significant if $p<0.05$.

\section{RESULTS}

\section{Cloning Panulirus shal 1 (Kv4)}

As a first step toward defining the molecular basis of the $\mathbf{I}_{\mathrm{A}} \mathrm{s}$ in pyloric neurons, we cloned the complete ORF of a Panulinis shal cDNA molecule. We first cloned the conserved core of the Panulirus shal cDNA (amino acids 46-406; Fig. 1) using degenerate primers in an RNA-PCR containing total RNA from the lobster nervous system (Baro et al., 1994a). To obtain the rest of the shal $\mathrm{K}^{+}$channel cDNA, we screened four cDNA libraries. Because the Shaker family clones were present in extremely low abundance in all four libraries, we used PCR for our initial screens of these librarics with Panulirus shal-specific primers 1 and 2 (Fig. 1) as described in Materials and Methods. When a positive clone was found in a pool of $\sim 5 \times 10^{4}$ clones, conventional plaque-lift techniques were used to isolate the clone.

Screening 2 million plaques from an abdominal ganglion cDNA library (Stratagene) produced no positive clones, whereas a screen of 1.5 million plaques from a thoracic ganglion cDNA library (Stratagene) and 3.3 million plaques from a cerebral ganglion cDNA library (Stratagene) produced three positive clones from each library (Fig. 1). Five of the six clones contained the $5^{\prime}$ end of the ORF and a portion of the $5^{\prime}$ untranslated region (UTR). However, all six clones isolated from the Stratagene oligo-dTprimed libraries unexpectedly ended in an internal XhoI site at nucleotide 1453 , and thus lacked the $3^{\prime}$ end of the ORF. It is not clear why the cDNA molecules had been cleaved by XhoI during the cloning process. Apparently, it is a sequence-specific artifact of the Stratagene cloning procedure because only one of four possible XhoI sites was ever cleaved (Fig. 1), and $>80 \%$ of the clones in the Stratagene libraries end in a stretch of poly(A) followed by an XhoI site as expected.

To obtain the portion of the cDNA coding for the carboxy end of the protein, we screened a fourth cDNA library, which we constructed from a mixture of abdominal, thoracic, and cerebral ganglia mRNA using a different cloning procedure, as described in Materials and Methods. We screened 3 million plaques and obtained one positive clone, whose $5^{\prime}$ end overlapped with the other six clones and whose $3^{\prime}$ end extended beyond the coding region into the $3^{\prime}$ UTR (Fig. 1 ).

\section{Nucleotide sequence analysis}

Both strands of all seven clones were sequenced, and overlapping regions were aligned; the resulting composite shal 1 (Kv4) sequence is shown in Figure 2. The clones are identical at the nucleotide level in extensive regions of overlap (Fig. 1), indicating that they were transcribed from the same shal gene. In addition, all seven clones are identical to the original shal core isolated in an RNA-PCR (Fig. 1).

There is one long ORF in this sequence consisting of $1,782 \mathrm{bp}$, which presumably includes the protein-coding region of the transcript. We defined the first methionine codon in the ORF as the start codon, because the nucleotide sequence surrounding this codon agrees with the Kozak consensus sequence (Kozak, 1989), and because it agrees with the start codon of the shal proteins in other species (Wei et al., 1990; Baldwin et al., 1991; Pak et al., 1991; Roberds and Tamkun, 1991). The sequences immediately $5^{\prime}$ and $3^{\prime}$ to the ORF most likely represent the untranslated $5^{\prime}$ and $3^{\prime}$ UTRs of the cDNA rather than introns, because there are no splice donor/acceptor sites (Padgett et al., 1986) in the proximity of the ORF/UTR junctions. There are no splice acceptor sites in the $5^{\prime}$ UTR, but there is a putative splice donor site in the $3^{\prime}$ UTR at position 1757 . We do not have enough information to determine whether this is the beginning of an intron or a continuation of the $3^{\prime}$ UTR. Sequence data from clone T2 indicates that the mRNA extends for an undetermined distance in the $5^{\prime}$ direction. Similarly, the lack of polyadenylation signals (Nevins, 1983) in the 3' UTR suggests that we do not have the complete mRNA.

\section{Amino acid sequence analysis}

The predicted length of the Panulirus shal 1 protein is 575 amino acids. Figure 2 aligns the lobster shal amino acid sequence with the fly (Wei et al., 1990), rat (Baldwin et al., 1991), and mouse (Pak et al., 1991) homologs. The shal subfamily appears to have

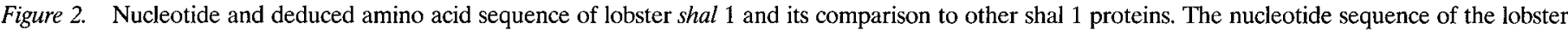

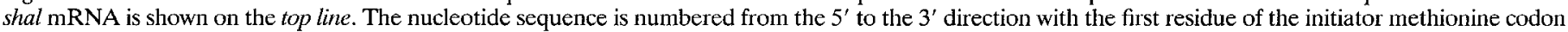

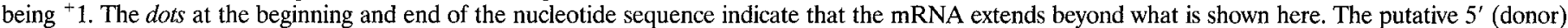

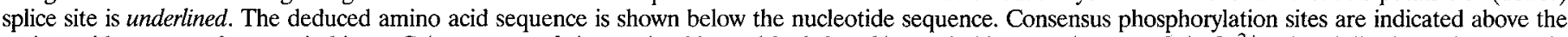

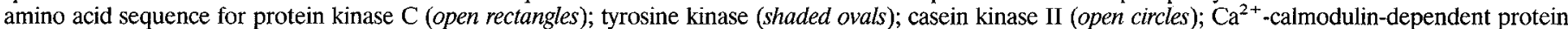

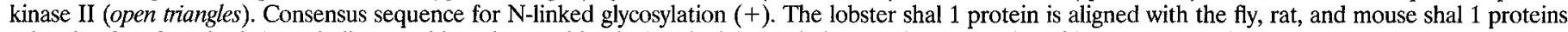

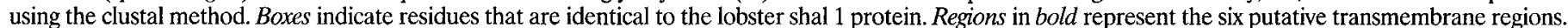

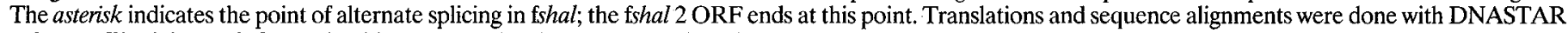
software. The lobster shal 1 nucleotide sequence has been processed by the Genome Sequence Data Base under accession number L49135. 
diverged to a lesser extent between vertebrates and invertebrates than the other three shaker subfamilies (Strong et al., 1993). The homology across all species extends beyond the conserved core to the amino terminus. The carboxy terminus is less well conserved, with the homology between the lobster and the other three species ending abruptly at R533. The amino acids $3^{\prime}$ to this point may represent the site of species-specific interactions with other cellular proteins, or regions of the protein where function does not depend on structure. The lobster and fly shal 1 proteins are $82 \%$ identical over their entire length, whereas the identity between lobster and mammalian shal homologs ranges from $\sim 65$ to $70 \%$.

The basic structure of Shaker family proteins is well conserved in lobster shal, as are several functional domains (Chandy and Gutman, 1995). The 44 amino acid positions showing complete identity among all known mammalian and fly Kv proteins (Chandy and Gutman, 1995) are also identical in lobster shal. Transmembrane region S4 (amino acids T291-R311), which is thought to be a major component of the voltage sensor in $\mathrm{K}^{+}$channels (Chandy and Gutman, 1995), is identical across species. The pore-forming region (amino acids I357-P378) is identical except for a single amino acid substitution in the lobster (S359). The tetramerization domain has not yet been defined for shal. However, this domain has been localized to a fragment of 114 amino acids in the N-terminal region of shaker proteins (Li et al., 1992; Shen et al., 1993), and the analogous region (roughly, amino acids L26 or D39 through $\mathrm{K} 152$ ) is well conserved in the shal proteins of all species. Unlike mouse and fly, the lobster shal protein has no functional $\mathrm{N}$-linked glycosylation sites (Hubbard and Ivatt, 1981; Kornfeld and Kornfeld, 1985); all putative glycosylation sites (Fig. 2) are intracellular according to current models of protein folding (Chandy and Gutman, 1995).

Because $\mathrm{I}_{\mathrm{A}} \mathrm{S}$ in Panulirus neurons are subject to modulation (Harris-Warrick et al., 1995a,b), we examined the protein for possible phosphorylation sites (Fig. 2). Some phosphorylation consensus sequences are not well defined, and some sites have a stronger recognition sequence than others (Aitken, 1990). We have listed all possible sites in Figure 2. There are no cAMPdependent or cGMP-dependent phosphorylation sites (Krebs and Beavo, 1979; Aitken, 1990). However, there are numerous putative phosphorylation sites for other kinases: 8 for protein kinase $\mathrm{C}$ (Kishimoto et al., 1985; Woodgett et al., 1986), 3 for $\mathrm{Ca}^{2+}$ calmodulin-dependent protein kinase II (Aitken, 1990), 9 for casein kinase II (Kuenzel et al., 1987; Aitken, 1990), and 11 for tyrosine kinase (Aitken, 1990). Of the 31 putative phosphorylation sites, 2 are extracellular and 4 are in the transmembrane regions, assuming the conventional folding pattern (Chandy and Gutman, 1995). Some phosphorylation sites overlap or are clustered and may represent sites of interaction between different kinases. For instance, phosphorylation of S114 changes a neutral serine residue into an acidic phosphoserine residue, which in turn increases the effectiveness or recognition of the phosphorylation sites at T113 and Y115 (Aitken, 1990). While many sites are conserved across species, others are not; for example, the lobster homolog contains the universal PKC site at T316 (Chandy and Gutman, 1995), but it lacks the cAMP-dependent phosphorylation site at amino acid residue 38 , which has been surmised to play a role in the regulation of the kinetics of inactivation in rat and Drosophila (Baldwin et al., 1991).

\section{Mapping introns}

Alternate splicing is a common mechanism for generating $\mathrm{K}^{+}$ channel diversity (Chandy and Gutman, 1995). So far, alternate

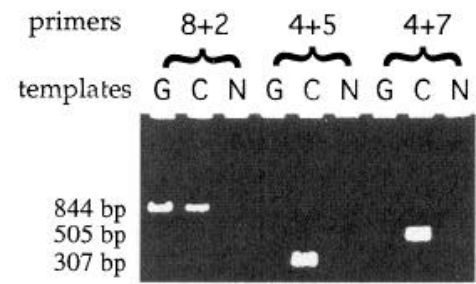

Figure 3. Mapping introns. Nine PCRs were carried out with one of three shal-specific primer sets: 8 and $2(8+2) ; 4$ and $5(4+5)$; or 4 and $7(4+7)$ (see Materials and Methods and Fig. 1 for descriptions of the primers). A standard 30 cycle PCR paradigm was used with the reaction conditions described in Materials and Methods and with an annealing temperature of $53^{\circ} \mathrm{C}$. The template in each PCR was either $100 \mathrm{ng}$ of genomic DNA $(G)$, $100 \mathrm{ng}$ of a cloned cDNA $(C)$, or no DNA $(N)$. Aliquots of the completed PCRs were run on a $2 \%$ agarose gel. Sizes are indicated in base pairs $(b p)$.

splicing of the shal gene has been found only at the $3^{\prime}$ end of the Drosophila transcript (Wei et al., 1990). Because we obtained only one clone containing the $3^{\prime}$ end of the transcript, we were unable to compare multiple clones for alternate splicing. We looked for the possibility of alternate splicing in the lobster shal gene by mapping the position of introns using PCRs with either genomic DNA or cDNA as the template. If there is no intron between two primers, the PCR products from genomic DNA and cDNA will be the same size. If there is an intron present between two primers, the genomic PCR product, which includes the intron, will be larger than the cDNA PCR product, and is often too great to be amplified efficiently in a standard PCR.

We found no evidence for alternate splicing at the amino end of the lobster shal 1 protein (Fig. 3 ). The $5^{\prime}$ end of the transcript is contained within one long exon, including the region beginning in the $5^{\prime}$ UTR (nucleotide -223) up through the end of the first putative membrane-spanning region, S1 (nucleotide 621). Because we screened our libraries with a probe contained within this exon, it is possible that alternate $5^{\prime}$ exons exist but were not detected with our screening procedure. There is at least one intron present between the last membrane-spanning region, S6, and the carboxy terminus (between nucleotides 1153 and 1460). This implies that alternate splicing is possible in the carboxy region of the lobster shal 1 protein, although we have no proof that alternate exons exist.

\section{Characterization of the lobster shal 1 (Kv4) current}

To begin to understand the contribution of the shal current to the $\mathrm{I}_{\mathrm{A}}$ in different pyloric neurons, we first characterized the Panulirus shal 1 current in a Xenopus oocyte expression system. Clone $\mathrm{K} / \mathrm{S} 10$, which contains the complete ORF of the Panulirus shal 1 gene, was constructed as described in Materials and Methods. Capped transcripts were made from clone $\mathrm{K} / \mathrm{S} 10$ and injected into Xenopus oocytes. After 2-5 d, a two-microelectrode voltage clamp was used to study the resulting current.

Like all known shal currents, the lobster shal 1 current is a fast transient $\mathrm{K}^{+}$current elicited by a hyperpolarizing prepulse to remove resting inactivation, followed by a depolarizing test pulse (Fig. 4). The time-to-peak for a $+20 \mathrm{mV}$ test pulse at $16^{\circ} \mathrm{C}$ is roughly $11 \pm 0.37 \mathrm{msec}, n=17$. The kinetics of activation of the lobster shal current were rapid and could not be accurately measured with our standard clamp protocol. The kinetics of inactivation for this current are also rapid and biphasic. Approximately $78 \%$ of the peak current inactivates with a fast time constant of 31 msec for a $+20 \mathrm{mV}$ test pulse at $16^{\circ} \mathrm{C}$. The remaining $22 \%$ of the 
A.
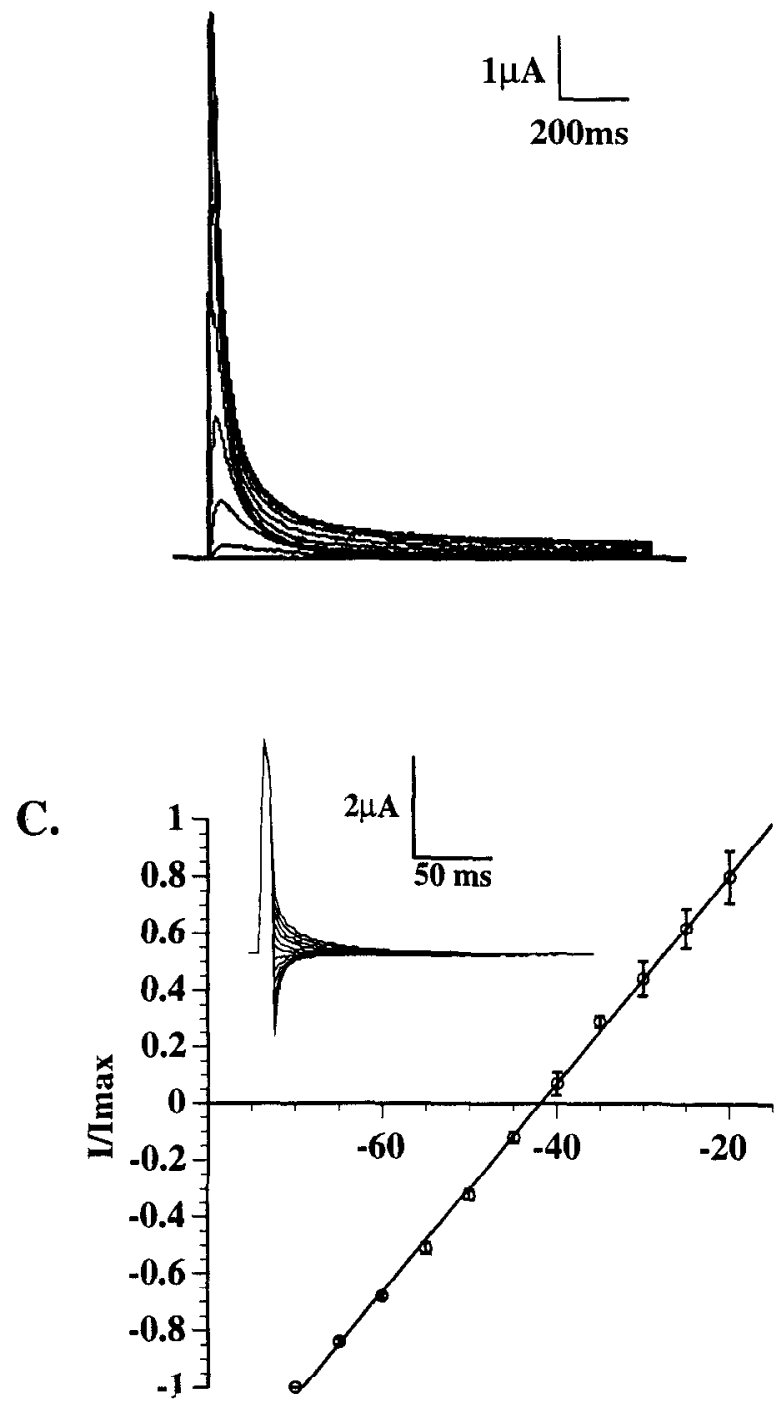

Voltage (mV)
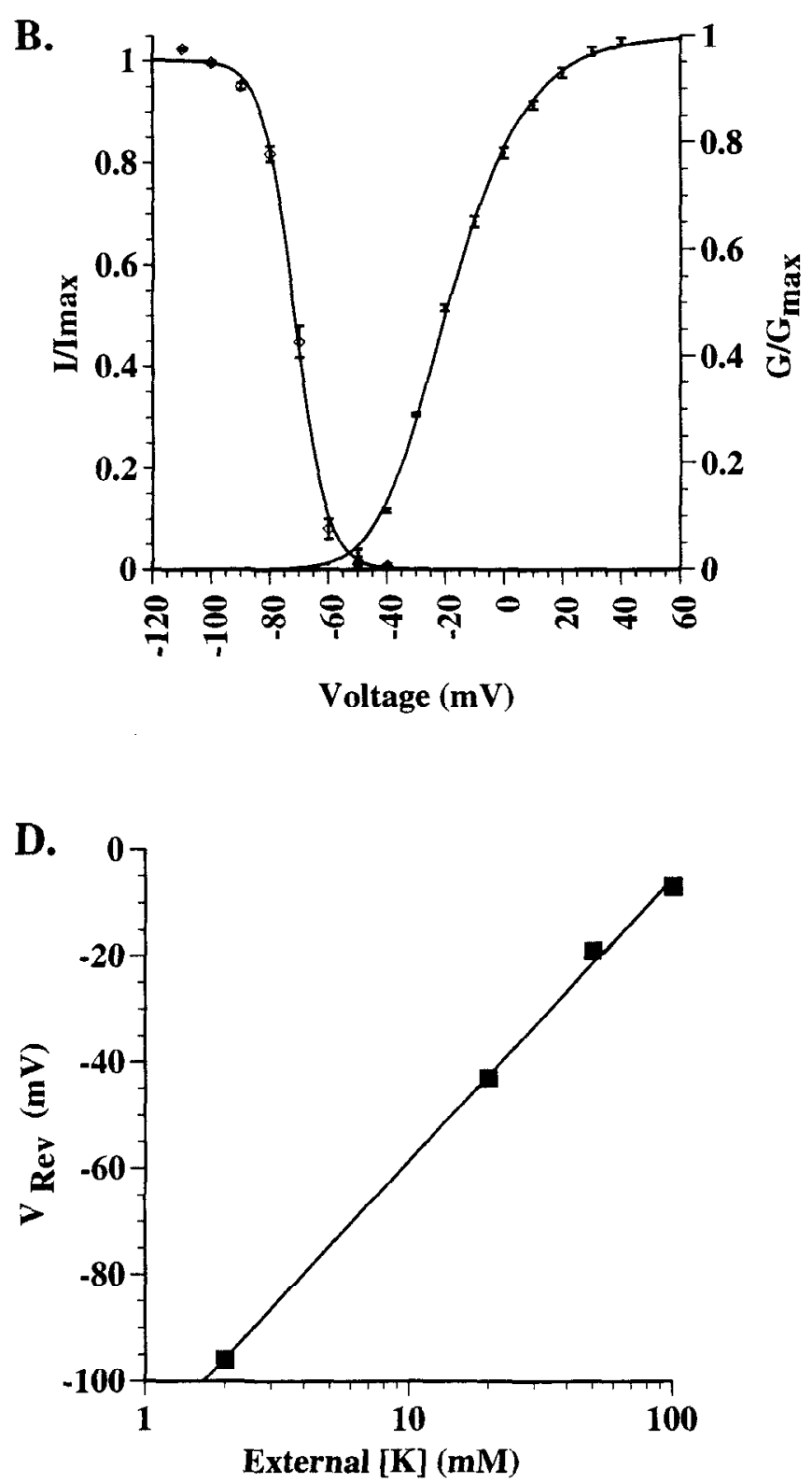

Figure 4. Characterization of Panulirus shal. A, Family of Panulirus shal current traces. Current traces are from voltage-clamp recordings of Xenopus oocytes injected with $\mathrm{K} / \mathrm{S} 10 \mathrm{cRNA}$. The cells were held at $-50 \mathrm{mV}$, and outward currents were evoked by a hyperpolarizing prepulse to $-90 \mathrm{mV}$ for 1.5 $\mathrm{sec}$, followed by a series of depolarizing test pulses for $1.35 \mathrm{sec} . B$, Voltage dependence of activation and inactivation. The activation (filled diamonds; $n=20$ ) and inactivation (open diamonds; $n=16$ ) curves for the shal current are shown. Curves were obtained as described in Materials and Methods. Parameter values were obtained from a curve fit to averaged data, whereas standard errors were determined from curve fits of the individual cells. $C$, Obtaining the reversal potential in $20 \mathrm{~mm}$ external $\mathrm{K}^{+}$. Averaged normalized instantaneous current values from five cells are plotted as a function of voltage to obtain the reversal potential. A representative set of tail currents in $20 \mathrm{~mm}$ external $\mathrm{K}^{+}$is shown as an inset above the plot. $D$, Relationship between reversal potential and external $\mathrm{K}^{+}$concentration. Reversal potentials for the Panulinus shal current in $2,20,50$, and 100 mM external $\mathrm{K}^{+}$were obtained as described in $C$, except that the range of the repolarizing steps varied with the potassium concentration ([K $\left.\left.\mathrm{K}^{+}\right]\right)$. Reversal potentials are plotted as a function of $\left[\mathrm{K}^{+}\right]$. The solid line is a linear regression fit to the data points.

peak current inactivates slowly with a time constant of $220 \mathrm{msec}$ (Table 1).

The activation of the shal current is voltage-dependent. The voltage at which conductance is half-maximal is $-19 \mathrm{mV}$. When the averaged, normalized peak conductance/voltage relation is fit to a third-order Boltzmann equation (Fig. $4 B$, filled diamonds), the voltage of half activation for individual gating steps and the e-fold slope factor are $-40 \mathrm{mV}$ and $15 \mathrm{mV}$, respectively (Table 1). The steady-state inactivation curve (Fig. 4B, open diamonds) was obtained by plotting the averaged, normalized peak current against the prepulse voltage and fitting the data points to a first-order Boltzmann equation. The peak current is reduced to half-maximal at $-71 \mathrm{mV}$, and the e-fold slope factor is $5.3 \mathrm{mV}$ (Table 1).

Lobster shal 1 is insensitive to $5 \mathrm{~mm}$ TEA $(n=4)$ and is reversibly blocked by $5 \mathrm{~mm} 4$-aminopyridine (4-AP) after $40 \mathrm{~min}$ (reduced $95.3 \pm 2.6 \% ; n=5$ ). Lobster shal displays a $\mathrm{K}^{+}$ dependence characteristic of an almost perfectly $\mathrm{K}^{+}$-selective channel. Tail currents were used to determine the instantaneous current-voltage relationship in different concentrations of exter- 
Table 1. Properties of $I_{A} s$

\begin{tabular}{|c|c|c|c|c|c|c|c|c|}
\hline Currents & $\begin{array}{l}\tau \text { fast }^{a} \\
(\mathrm{msec})\end{array}$ & $\begin{array}{l}\tau \text { slow }^{a} \\
(\mathrm{msec})\end{array}$ & $\begin{array}{l}\text { Amplitude }{ }^{a} \\
\left(\tau_{\text {fast }}\right)\end{array}$ & $\begin{array}{l}\text { Amplitude }^{a} \\
\left(\tau_{\text {slow }}\right)\end{array}$ & $\begin{array}{l}\text { Activation }^{b} \\
V_{1 / 2}(\mathrm{mV}) \\
\end{array}$ & $\begin{array}{l}\text { Activation }{ }^{b} \\
\text { slope factor } \\
(\mathrm{mV})\end{array}$ & $\begin{array}{l}\text { Inactivation }^{b} \\
V_{1 / 2}(\mathrm{mV})\end{array}$ & $\begin{array}{l}\text { Inactivation }^{b} \\
\text { slope factor } \\
(\mathrm{mV})\end{array}$ \\
\hline \multirow[t]{2}{*}{ Panulirus shal } & $31 \pm 1$ & $220 \pm 7$ & $0.78 \pm 0.01$ & $0.22 \pm 0.01$ & $-40 \pm 0.4$ & $15 \pm 0.4$ & $-71 \pm 0.7$ & $5 \pm 0.2$ \\
\hline & $n=16$ & $n=16$ & $n=16$ & $n=16$ & $n=16$ & $n=16$ & $n=16$ & $n=16$ \\
\hline \multirow[t]{2}{*}{$\mathrm{PY} \mathrm{I}_{\mathrm{A}}$} & $25 \pm 4$ & $107 \pm 11^{1}$ & $0.36 \pm 0.03^{1}$ & $0.64 \pm 0.03^{1}$ & $-40 \pm 1.5$ & $14 \pm 0.4^{1}$ & $-63 \pm 2.7^{1}$ & $7 \pm 0.9$ \\
\hline & $n=7$ & $n=7$ & $n=7$ & $n=7$ & $n=8$ & $n=8$ & $n=6$ & $n=6$ \\
\hline \multirow[t]{2}{*}{$\mathrm{LP} \mathrm{I}_{\mathrm{A}}$} & $27 \pm 2^{1}$ & $104 \pm 8^{1}$ & $0.35 \pm 0.04^{1}$ & $0.65 \pm 0.04^{1}$ & $-33 \pm 1.5^{1,2}$ & $25 \pm 1.3^{1,2}$ & $-63 \pm 1.4^{1}$ & $8 \pm 2.9$ \\
\hline & $n=7$ & $n=7$ & $n=7$ & $n=7$ & $n=8$ & $n=8$ & $n=3$ & $n=3$ \\
\hline \multicolumn{9}{|l|}{ Drosophila } \\
\hline \multirow[t]{2}{*}{ shal } & $74 \pm 2^{1}$ & $275 \pm 4$ & $0.44 \pm 0.02^{1}$ & $0.56 \pm 0.02^{1}$ & $-36 \pm 0.8^{1}$ & $22 \pm 0.8^{1}$ & $-66 \pm 0.3^{1}$ & $9 \pm 0.6^{1}$ \\
\hline & $n=13$ & $n=13$ & $n=13$ & $n=13$ & $n=13$ & $n=13$ & $n=13$ & $n=13$ \\
\hline
\end{tabular}

${ }^{a}$ Values obtained from Equation 1 in Materials and Methods.

${ }^{b}$ Values obtained from Equation 2 in Materials and Methods.

${ }^{1}$ Significantly different from Panulirus shal $(p<0.05)$.

${ }^{2}$ Significantly different from PY $\mathrm{I}_{\mathrm{A}}(p<0.05)$.

nal $\mathrm{K}^{+}$(Fig. 4C). The tail-reversal potentials were plotted against the $\log$ of the external $\mathrm{K}^{+}$concentration (Fig. 4D). A leastsquares linear regression of the data points had a slope of $53 \mathrm{mV}$ per 10 -fold change in external $\mathrm{K}^{+}$concentration, a value close to the $57.3 \mathrm{mV}$ slope predicted from the Nernst equation.

\section{Determining shal gene expression in the LP and PY cells}

To determine whether shal could be contributing to the $\mathrm{I}_{\mathrm{A}} \mathrm{s}$ in the LP and PY cells, we used a single-cell RT-PCR method to determine whether the shal gene was expressed in these cells. The single-cell RT-PCR technique we developed for stomatogastric neurons will be described in detail elsewhere (Baro et al., unpublished data). Briefly, we identify the LP and PY cells electrophysiologically, remove the glial caps from the neurons because shal is expressed in glial cells (Baro et al., unpublished data), isolate the soma and initial segment with a glass micropipette, expell the cell into a microfuge tube, and perform an RT-PCR on the individual neuron. Shal-specific primer 6 served as the RT primer, and shal-specific primers 4 and 5 as the PCR primers (Fig. 1). Because these primers span an intron (Fig. 3), wc arc surc wc are detecting cellular RNA and not chromosomal DNA. The presence of a 308 bp band in the RT-PCRs containing a single LP or PY neuron as the template (Fig. 5) indicates that the shal gene is expressed in these cells. Shal was expressed in all LP $(n=10)$ and PY $(n=21)$ neurons we examined.

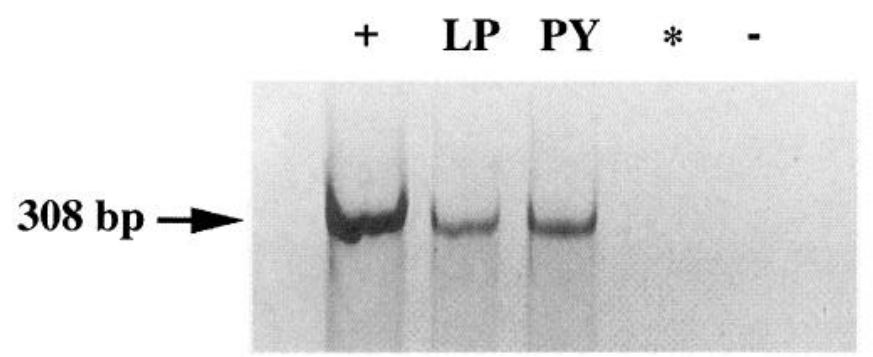

Figure 5. Shal gene expression in the LP and PY cells. Single-cell RTPCRs were performed as described previously (Baro et al., unpublished data). The RT-PCR product was run on a $10 \%$ polyacrylamide gel and stained with ethidium bromide. The template in each lane is as follows: + , Cloned shal 1 cDNA; -, H20;, $\mathrm{H} 20 ; L P$, a single LP neuron lacking its glial cap; $P Y$, a single PY neuron lacking its glial cap.

\section{Comparison of the shal current to the LP and PY $\mathrm{I}_{\mathrm{A}} \mathrm{s}$}

To study the role of shal in generating the $\mathrm{I}_{\mathrm{A}}$ in pyloric neurons, we compared the lobster shal 1 current expressed in Xenopus oocytes with the endogenous $\mathrm{I}_{\mathrm{A}} \mathrm{s}$ in the LP and PY cells, which are also 4-AP-sensitive and TEA-insensitive (Tierney and HarrisWarrick, 1992). A two-microelectrode voltage clamp was used to study the activation and inactivation properties of the $\mathrm{I}_{\mathrm{A}} \mathrm{s}$ in the LP and PY cells. Figure 6 shows a comparison of the pyloric cells' $\mathrm{I}_{\mathrm{A}} \mathrm{s}$ with the lobster shal current.

The LP and PY $\mathrm{I}_{\mathrm{A}}$ traces, evoked by a step to $+20 \mathrm{mV}$, are directly superimposable when normalized for amplitude (Fig. 6A). The $I_{A}$ traces of the pyloric cells are similar to the shal current trace, but not identical. The shal current appears to be slower to rise and initially faster to fall. The time-to-peak of the shal current (11 msec) is approximately twice that of the pyloric $\mathrm{I}_{\mathrm{A}} \mathrm{s}(5 \pm 0.46$ msec; $n=15$ ). The LP I $_{\mathrm{A}}$ 's and PY $\mathrm{I}_{\mathrm{A}}$ 's fast time constants of inactivation are slightly faster than that of the shal current, whereas their slow time constants of inactivation are twofold faster (Table 1). These values are unexpected since the $I_{A} s$ of the pyloric cells abate more slowly than the shal current (Fig. 6A). The explanation for this apparent discrepancy is that a significantly smaller fraction of the peak current inactivates with the fast time constant in the pyloric cells. Only $35 \%$ of the peak $\mathrm{I}_{\mathrm{A}}$ inactivates with the fast time constant in pyloric cells. In contrast, $80 \%$ of the peak shal current inactivates with the fast time constant. Thus, slow inactivation dominates the $\mathrm{I}_{\mathrm{A}}$ in pyloric neurons, whereas fast inactivation dominates the shal current in oocytes $(p<0.01$; Table 1).

The voltage activation curves for the $\mathrm{PY} \mathrm{I}_{\mathrm{A}}$ and the shal current are almost directly superimposable (Fig. $6 B$ ). The voltages of half activation $\left(V_{1 / 2}\right)$ obtained from the Boltzmann distributions are identical, and the slope factors differ by only $1 \mathrm{mV}$ (Table 1$)$. The LP $\mathrm{I}_{\mathrm{A}}$ activation curve, on the other hand, is significantly different (Fig. $6 B$ ); the $V_{1 / 2}$ is $7 \mathrm{mV}$ more depolarized, and the slope factor is at least 1.6-fold larger than the values for the $\mathrm{PY} \mathrm{I}_{\mathrm{A}}$ and shal activation curves (Table 1).

Unlike the activation curves, the voltage inactivation curves for the pyloric $\mathrm{I}_{\mathrm{A}} \mathrm{s}$ are superimposable (Fig. 6C). The lobster shal voltage inactivation curve is shifted $8 \mathrm{mV}$ in the hyperpolarizing direction relative to the inactivation curves of the pyloric cells, and its slope factor differs by $26 \%\left(\mathrm{PY} \mathrm{I}_{\mathrm{A}}\right)$ and $33 \%\left(\mathrm{LP} \mathrm{I}_{\mathrm{A}}\right)$. 

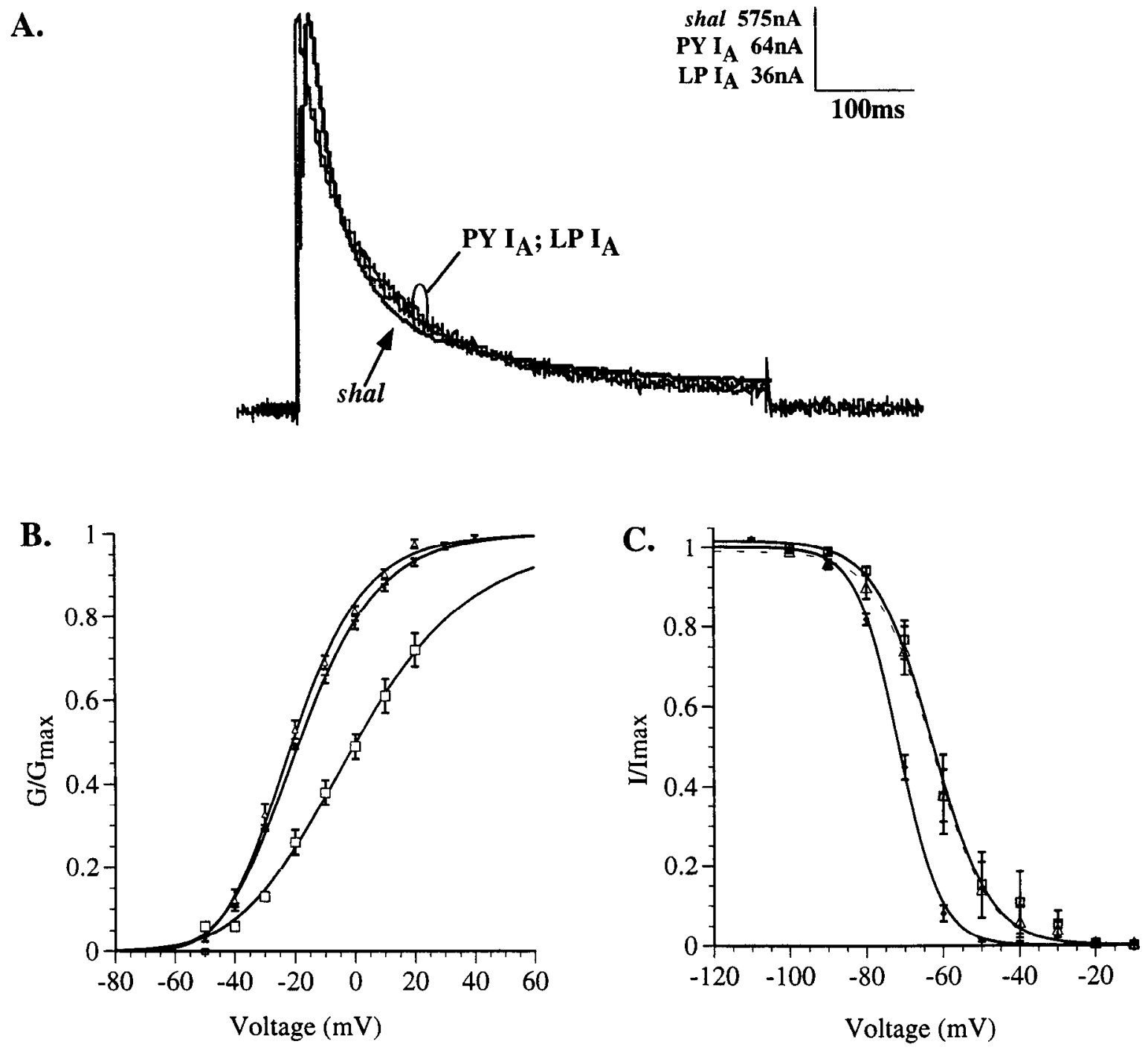

Figure 6. Comparison of the Panulirus shal current expressed in Xenopus oocytes to A-currents $\left(I_{\mathrm{A}}\right)$ in pyloric cells. $A$, Comparison of $P Y I_{\mathrm{A},} L P I_{\mathrm{A}}$, and shal current (shal) traces. Currents were elicited from a $-50 \mathrm{mV}$ holding potential by a hyperpolarizing prepulse followed by a step to $+20 \mathrm{mV}$. Representative current traces were subtracted as described in Materials and Methods. Traces were scaled to the sanne size and aligned according to the time scale. $B$, Activation curves. Averaged, normalized peak conductances are plotted against test-pulse voltages (filled diamonds, Panulinus shal, $n=20$; open triangles, $\mathrm{PY} \mathrm{I}_{\mathrm{A}}, n=8$; open squares, $\mathrm{LP} \mathrm{I}_{\mathrm{A}}, n=7$ ). Activation curves were obtained as described in Materials and Methods. $C$, Inactivation curves. Averaged, normalized peak currents are plotted against prepulse voltages (filled diamonds, Panulirus shal, $n=16 ;$ open triangles, PY $\mathbf{1}_{\mathrm{A}}, n=6$; open squares, $\mathrm{LP} \mathrm{I}_{\mathrm{A}}, n=3$ ). Inactivation curves were obtained as described in Materials and Methods.

\section{Comparison of the Panulirus and Drosophila shal currents}

We were also interested in whether the fly and lobster shal currents would be distinguishable given their high degree of amino acid identity. The Drosophila shal transcript is alternately spliced to produce two proteins (Wei et al., 1990). The only difference between the Drosophila shal 1 and 2 proteins is that there are an extra 81 amino acids at the carboxy terminus of the fly shal 1 protein that are absent from the fly shal 2 protein (Fig. 2 ). The two fly shal currents have comparable functional properties (Pak et al., 1991). Similarly, the Drosophila shal 2 protein and the Panulirus shal 1 protein are $89 \%$ identical over the entire length of the fly shal 2 protein, but the lobster shal 1 protein has an additional 85 amino acids at the carboxy terminus (see Fig. 2). We expressed the Drosophila clone, shal 2 (Wei et al., 1990), in Xenopus oocytes and compared the resulting $\mathbf{I}_{\mathrm{A}}$ to the Panulirus shal 1 current obtained under identical conditions (Fig. 7).
As shown in Figure $7 A$, despite the high degree of sequence conservation, the two current traces are not identical. The kinetics of activation and inactivation are different for the two currents, with the Drosophila current being slower to rise and fall. The time-to-peak for a test pulse to $+20 \mathrm{mV}$ was $19 \pm 0.72 \mathrm{msec}(n=$ 13) for the Drosophila shal current, which is significantly slower than the Panulirus shal current $(p<0.01)$. The fast time constant of inactivation is 2.4 times faster in Panulirus compared with Drosophila ( $p<0.01$; Table 1$)$. The slow time constant of inactivation is also $20 \%$ faster in Panulirus, although this difference is not statistically significant (Table 1). The relative contributions of the rapidly and slowly inactivating components differ in the two currents as well. The slow component makes a more substantial contribution to the peak current in Drosophila (56\%) than Panulinus (22\%; Table 1).

Both the activation curves (Fig. $7 B$ ) and the inactivation curves (Fig. $7 C$ ) are statistically distinct for the lobster and fly shal 

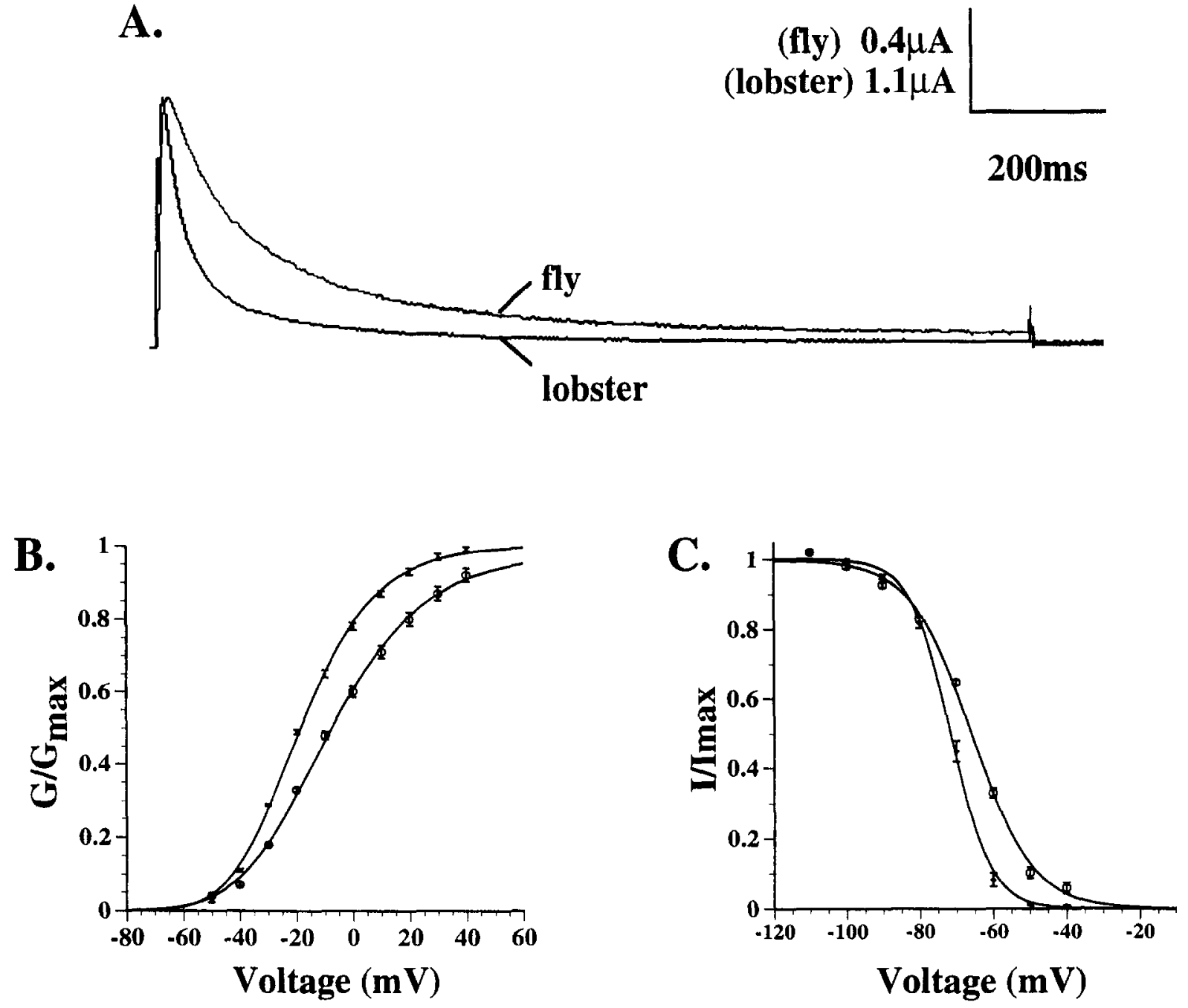

Figure 7. Comparison of Panulirus shal 1 and Drosophila shal 2 currents. $A$, Representative Panulirus and Drosophila current traces. The current traces are from voltage-clamp recordings of oocytes injected with either lobster or fly shal cRNA. Currents were obtained under identical conditions. The traces shown here were elicited by a prepulse to $-90 \mathrm{mV}$ followed by a test pulse to $+20 \mathrm{mV}$. The traces were subtracted as described in Materials and Methods. The amplitudes of the currents were scaled to the same size, and the traces were aligned according to the time scale. $B$, Voltage activation curves. Averaged, normalized peak conductances are plotted against the test-pulse voltage (filled diamonds, Panulirus shal, $n=20 ;$ open circles, Drosophila shal, $n=13$ ). $C$, Voltage inactivation curves. Averaged, normalized peak currents are plotted against the prepulse voltage (filled diamonds, Panulirus shal, $n$ $=16 ;$ open circles, Drosophila shal, $n=13$ ).

currents. The voltages of half activation obtained from a thirdorder Boltzmann distribution (Table 1) differ by $4 \mathrm{mV}$, and the slope factors differ by $29 \%$. The voltages of half inactivation obtained from a first-order Boltzmann distribution (Table 1) differ by $5 \mathrm{mV}$, and the slope factors differ by $38 \%$.

The results we obtained for the Drosophila shal voltage activation curve are consistent with those obtained by Pak et al. (1991), but there are some inconsistencies for the voltage inactivation curve. The voltage of half inactivation is shifted by $3 \mathrm{mV}$ in the hyperpolarizing direction in our measurements, and the e-fold slope factor is less steep. This could be attributable to differences in the recording conditions. In particular, we did not routinely include 4,4-diisothiocyanostilbene-2,2'-disulfonic acid (DIDS) in our solutions to block $\mathrm{I}_{\mathrm{Cl}(\mathrm{Ca})}$, because we previously observed that DIDS alters the voltage dependence of the lobster shal current (Baro and Coniglio, unpublished). The time constants of inactivation that we measured are approximately twice as slow as the time constants obtained by Pak et al. (1991), but this is most likely due to the lower temperature at which our recordings were made $\left(16^{\circ} \mathrm{C}\right.$ vs $\left.23^{\circ} \mathrm{C}\right)$. All our recordings from Panulirus neurons are done at $16^{\circ} \mathrm{C}$, because this is the average water temperature of the Panulirus habitat. To compare the results obtained from oocytes and neurons, oocyte recordings also werc done at this temperature.

\section{DISCUSSION}

The 14 neurons in the pyloric network fall into six major cell types. These cell types are heterogeneous with respect to $\mathbf{I}_{\mathrm{A}}$, and this heterogeneity plays an important role in shaping the pyloric motor pattern. As a first step toward understanding the molecular basis for $I_{A}$ heterogeneity in the pyloric network, we are trying to determine which Shaker family genes underlie the $\mathrm{I}_{\mathrm{A}} \mathrm{s}$ in identified pyloric cells. In systems that are not as genetically tractable as Drosophila, endogenous $\mathrm{K}^{+}$currents and specific genes have been linked by comparing physiologically defined currents in identified cells with currents obtained by cloning and overexpressing $\mathrm{K}^{+}$ channel genes (Pfattinger et al., 1991; Kaang et al., 1992; Quattrocki et al., 1994). Because the shal gene encodes an $\mathrm{I}_{\mathrm{A}}$ in all 
systems studied to date, and because shal is expressed in most stomatogastric neurons (Baro et al., unpublished data), we have used this approach to explore the relationship between Panulirus shal (Kv4) and the $I_{\wedge} s$ in the LP and PY cells.

\section{Comparing Panulirus shal (Kv4), PY I $\mathrm{A}_{\mathrm{A}}$ and LP I}

The Panulinus shal I (Kv4) cDNA was cloned. After determining that the shal 1 gene was expressed in the LP and PY cells, we compared the shal 1 current obtained from an oocyte expression system to the $I_{\Lambda} s$ in the LP and PY cells. As expected, expression of Panulius shal 1 channels resulted in a fast, transient, voltagedependent $K^{+}$current in oocytes. Like the native pyloric $I_{\Lambda} s$, the shal current was sensitive io 4-AP but insensitive to TEA. In addition, the voltage dependences of activation for the PY $\mathrm{I}_{\mathrm{A}}$ and the shal current were identical. However, while the shal current was similar to the $I_{A} s$ in the LP and PY cells in many respects, there were also a number of distinctions between these currents. Statistically significant differences were measured in the time-topeak, the kinctics of inactivation, and the voltage dependence of inactivation. Since the LP and PY cells express the shal 1 gene, we would argue that unless shal 1 channels are exclusively localized to the neuropil, shal must contribute to the somatic $I_{A} s$ in the LP and PY neurons. There are then several explanations that could account for the quantitative differences between the shal current and the endogenous lobster $\mathrm{I}_{\mathrm{A}} \mathrm{s}$.

First, our measurements of the somatic $I_{\Lambda}$ s may be inaccurate because of incomplete space clamp of the neuron. However, this seems unlikely because Hartline et al. (1993) hatve shown that space-clanperrors are small in this system and that peak currents reflect primarily somatic channels. The major effect of an incomplete space clamp on the parameters we measured would be to increase the slow time constant of inactivation in Panulirus neurons (Hartline and Castlefranco, 1994); yet, we observe that $\tau_{s}$ is larger in the oocyte shal current than the pyloric $\mathrm{I}_{\wedge} \mathrm{s}$. Thus, we believe that space-clamp crrors cannot explain the major differences we observe between the currents.

Second, the distinct cellular milieus of the oocyte and the pyloric neurons might introduce cell-specific differences in posttranslational modifications and second messenger-mediated modifications that could alter the properties of the currents. For example, we have shown that dopamine can decrease the $\mathrm{I}_{\mathrm{A}} \mathrm{s}$ in the LP and PY neurons by shifting the voltage dependence of activation and inactivation, and by changing the ratios of rapidly to slowly inactivating components (Harris-Warrick, 1995a,b). Similarly, Hevers and Hardic (1995) have shown that serotonin can shift the activation curve of the shaker current in Drosophila photoreceptor cells. Other studies have shown that kinases and phosphatases can regulate Shaker family $K$ ' channels and that moduation of inactivation gating is another important regulatory mechanism (Hoger et al., 1991; Zhong ed al., 1993; Covarrubias et al., 1994; Drain et al., 1994). Recently, Tsunoda and Salkoff demonstrated that the Drosophila shal channel can have multiple gating modes and that a single channel can switch from one mode to another (Tsunoda and Salkoff, 1995a). This led to a wide variety of inactivation rates in ensemble-averaged shal currents and whole-cell transicnt currents. Since modal gating of other channels can be modulated by changes in phosphorylation states (Wilson and Kaczmarek, 1993), I s carried by the same channels in different cells could display differences in their inactivation kinetics if the population of channels was in a unique phosphorylation state in each cell type. It is interesting that the Drosophila shal currents' $\tau_{\text {fast }}$ varied by more than a factor of 20 in cultured embryonic neurons (Tsunoda and Salkoff, 1995a), whereas such variability was never observed in Panulinus neurons or oocytes injected with either fly or lobster shal (Table 1, see also Pak et al., 1991).

A third possible explanation for the differences between the native currents and the shal current is the differential expression of proteins that interact with the Shaker family $\alpha$ subunits (Zhong and Wu, 1993; Rettig et al., 1994; Chouinard et al., 1995; Majumder et al., 1995; Morales et al., 1995). For example, a Drosophila $\beta$ subunit can modulate both the activation and inactivation properties of a $\mathrm{K}^{1}$ channel $\alpha$ subunit (Chouinard et al., 1995).

Fourth, other genes in addition to shal 1 may underlic some variable fraction of the pyloric cells' $I_{A}$ s. In our recently submitted paper, we used RT-PCR analysis of unidentified stomatogastric neurons to demonstrate that 100 and $94 \%$ of the neurons expressed the Shaker and shal 1 genes, respectively (Baro et al., unpublished data). Since the Drosophila shaker $\mathrm{I}_{\wedge}$ activates more rapidly than the shal current (Wei et al., 1990), shaker channels may underlie the more rapid activation of $I_{\wedge}$ in the LP and PY neurons. In addition, the levels of shal, and perhaps Shaker, geno expression differed among neurons. Thus, varying mixtures of Shaker and shat channels may generate distinct $I_{\wedge} s$ in pyloric neurons.

Finally, shal undergoes alternate splicing in Drosophila. Al though this does not lead to significant changes in the functional propertics of the Drosophila shal current measured in oocytes (Pak et al., 1991), it is possible that these alternate splice forms produce unique currents in native cells. Although we have yet to obtain evidence for alternate splicing of the Pamulirts shal transcript, we cannot discount this as a possible mechanism for generating $\mathrm{K}+$ current diversity.

\section{Comparing the shal currents from different species}

Our expression studies have shown that the shal channels from Drosophila and Panulirus can produce very different currents under identical experimental conditions, despite the high degree of conservation at the amino acid level. Every parameter we analyzed, except the slow time constant of inactivation, was significantly different between the two currents. The major distinction between the lobster shal 1 and Hy shal 2 proteins is the presence of an 85 amino acid tail at the carboxy terminus of the lobster protein (amino acids 491-575). The rest of the shal proteins, which we will refer to as the common region, are $89 \%$ identical between the two species. The addition of the 81 amino acid Drosophila tail onto the fly shal protein did not induce significant changes in the current (Pak et al., 1991), but the fly and lobster carboxy tails are only $31 \%$ identical and may have different effects on the protein.

The differences in the voltage dependenee of activation and the slope of the activation curve are striking, given that the S4 transmembranc region is identical in lobster and Drosophila shal. This cmphasizes the importance of other regions of the channel in determining its voltage dependenee of activation. Approximately $78 \%$ of the amino acid substitutions in the common region are conservative. Five of the eleven nonconservative substitutions (K161, R165, G170, L212, K216) introduce or remove a charged amino acid; four exchange a polar for a hydrophobic side chain, or vice-versa (V163, Q219, G232, F467); and only three do not change the type of side chain on the amino acid (Y162, P381, T468). Since it is thought that residues in regions other than S4 are involved in charge-sensing (Papazian et al., 1995), perhaps 
these changes can account for some of the differences we see between the two currents.

Another explanation for the differences we observe between lobster and fly shal currents might be the introduction or removal of phosphorylation sites. In the common region of the shal protein there are four putative phosphorylation sites present in the lobster homolog that are lacking in the fly protein (Fig. 2). Similarly, there are two sites present in the common region of the fly shal protein that are missing in lobster shal (T38 and Y468). In the carboxy tail, there are four putative phosphorylation sites in the lobster shal protein that are not present in the fly homolog (Fig. 2), and one site in fly shal (T565) that is missing in lobster shal. Thus, differences in phosphorylation states could account for some of the differences between the two currents.

A comparison of all the shal currents published to date suggests that there are major similarities and differences between species. The voltage of half-maximal conductance for lobster shal $(-19$ $\mathrm{mV})$ is very different than fly shal $(-7 \mathrm{mV})$, mouse shal $(-7 \mathrm{mV}$; Pak et al., 1991), and rat shal ( $-4 \mathrm{mV}$; Baldwin et al., 1991). The voltage dependence of half inactivation of the shal current is similar in lobster $(-71 \mathrm{mV})$, fly $(-66 \mathrm{mV})$, and mouse $(-69 \mathrm{mV}$; Pak et al., 1991), but not in rat $(-48 \mathrm{mV}$; Baldwin et al., 1991). Furthermore, if we compare strongly temperature-dependent phenomena recorded at the organisms' native temperatures, we find that the $\tau_{\text {fast }}$ is similar in lobster $\left(31 \mathrm{msec}\right.$ at $\left.16^{\circ} \mathrm{C}\right)$ and fly (38 msec at $23^{\circ} \mathrm{C}$; Pak et al., 1991), as is the time-to-peak (lobster = $11 \mathrm{msec}$ at $16^{\circ} \mathrm{C}$; fly $=12 \mathrm{msec}$ at $23^{\circ} \mathrm{C}$; Pak et al., 1991). One interpretation of these data is that some conserved function of invertebrate shal channels depends on these temperaturedependent phenomena, and in order to preserve these features, the genes have evolved to compensate for the temperature differences in the habitats of the organisms. It is unclear whether temperature-dependent phenomena are similarly compensated for in mammals, because the published records of the mammalian shal channels were not obtained at $37^{\circ} \mathrm{C}\left(\tau_{\text {fast }}\right.$ in the mouse and rat are $22 \mathrm{msec}$ at $23^{\circ} \mathrm{C}$ and $155 \mathrm{msec}$ at $11^{\circ} \mathrm{C}$, respectively), and the current decay was fit with three exponentials instead of two (Baldwin et al., 1991; Pak et al., 1991).

Perhaps species-specific differences in the shal current are minimized by other cell-specific phenomena in each organism, or maybe these differences are enhanced. In either event, our study points out the limitations of heterologous expression systems when trying to correlate a cloned $\mathrm{K}^{+}$channel gene to a physiologically defined current. Because the cellular environment plays such a large role in shaping a current, alternate approaches are required to determine the contribution of a specific $\mathrm{K}^{+}$channel gene to a current. Such approaches might include quantitation of Shaker family RNA in identified cells, antisense, or dominantnegative knock-outs of Shaker family gene expression, or expression of cloned genes in identified neurons. Integrating data from several of these approaches should lead to a better understanding of which channels underlie which currents.

\section{REFERENCES}

Aitken $\Lambda,(1990)$ Identification of protein consensus sequences: active site and DNA-binding motifs, phosphorylation, and other posttranslational modifications. New York: Ellis Horwood.

Ausubel FM, Brent R, Kinston RE, Moore DD, Seidman JG, Smith JA, Struhl K (1990) Current protocols in molecular biology. New York: Greene Publishing Associates and Wiley Interscience.

Baker K, Salkoff L (1990) The Drosophila shaker gene codes for a distinctive $\mathrm{K}^{+}$current in a subset of neurons. Neuron $2: 129-140$.
Baldwin T, Tsaur M-L, Lopez GA, Jan YN, Jan LY (1991) Characterization of a mammalian cDNA for an inactivating voltage-sensitive $\mathrm{K}^{+}$ channel. Neuron 7:471-483.

Barn D., Cole CI, 7arrin AR, Hughes S, Harris-Warrick RM. (1994a) Shab gene expression in identified neurons of the pyloric network in the lobster stomatogastric ganglion. Receptors Channels 2:193-205.

Baro DJ, Cole CL, Coniglio LM, Kim M, Lubell J, Rodriguez IIE, Herrera ME, Podleski TR, Harris-Warrick RM (1994b) Characterization of the shal subfamily in the spiny lobster. Soc Neurosci Abstr 20:24.

Chandy CK, Gutman GA (1995) Voltage-gated potassium channel genes. In: Handbook of receptors and channels: ligand- and voltagegated ion channels (North RA, ed), pp 1-71. Boca Raton: CRC.

Chomczynski P, Sacchi N (1987) Single step method of RNA isolation by acid guanidinium thiocyanate-phenol-chloroform extraction. Anal Biochem 162:156-159.

Chouinard SW, Wilson GF, Schlimgen AK, Ganetzky B (1995) A potassium channel $\beta$-subunit related to the aldo-keto reductase superfamily is encoded by the Drosophila hyperkinetic locus. Proc Natl Acad Sci USA 92:6763-6767.

Covarrubias M, Wei A, Salkoff L, Vyas TB (1994) Elimination of rapid potassium channel inactivation by phosphorylation of the inactivation gate. 13:1403-1412.

Drain P, Dubin AE, Aldrich RW (1994) Regulation of Shaker K ${ }^{+}$channel inactivation gating by the cAMP-dependent protein kinase. Neuron 12:1097-1109.

Elkins T, Ganetzky B (1988) The role of potassium currents in Drosophila flight muscle. J Neurosci 8:428-434.

Flamm RE, Harris-Warrick RM (1986) Aminergic modulation in the lobster stomatogastric ganglion. II. Target neurons of dopamine, octopamine and serotonin within the pyloric circuit. J Neurophysiol 55:866-881.

Golowasch J, Marder E (1992) Ionic currents of the lateral pyloric neuron of the stomatogastric ganglion of the crab. $J$ Neurophysiol $67: 318-331$.

Golowasch J, Buchholtz F, Epstein IR, Marder E (1992) Contribution of individual ionic currents to activity of a model stomatogastric ganglion neuron. J Neurophysiol 67:341-349.

Graubard K, Hartline DK (1991) Voltage clamp analysis of intact stomatogastric neurons. Brain Res 557:241-254.

Hanahan D (1983) Studies on transformation of Escheridria coli with plasmids. J Mol Biol 166:557.

Hardie RC, Voss D, Pongs O, Laughlin B (1991) Novel potassium channels encoded by the Shaker locus in Drosophila photoreceptors. Neuron 6:477-486.

Harris-Warrick RM, Marder E, Selverston AI, Moulins M (1992) Dynamic biological networks: the stomatogastric nervous system. Cambridge: MIT.

Harris-Warrick RM, Coniglio LM, Barazangi N, Guckenheimer J, Gueron $S$ (1995a) Dopamine modulation of transient potassium current evokes phase shifts in a central pattern generator network. J Neurosci 15:342-358.

Harris-Warrick RM, Coniglio LM, Levini RM, Gueron S, Guckenheimer J (1995b) Dopamine modulation of two subthreshold currents produces phase shifts in activity of an identified motoneuron. J Neurophysiol 74:404-420.

Hartline DK (1979) Pattern generation in the lobster (Panulinus) stomatogastric ganglion. II. Pyloric network simulation. Biol Cybern 33:223-236.

Hartline DK, Castlefranco AA (1994) Measurement errors from clamping voltage-dependent conductances in cells with elongate processes. Soc Neurosci Abstr 20:1526.

Hartline DK, Graubard K (1992) Cellular and synaptic properties in the crustacean stomatogastric nervous system. In: Dynamic biological networks: the stomatogastric nervous system (Harris-Warrick RM, Marder E, Selverston AI, Moulins M, eds), pp 31-86. Cambridge: Bradford Books/MIT.

Hartline DK, Gassie DV, Jones BR (1993) Effects of soma isolation on outward currents measured under voltage clamp in spiny lobster stomatogastric motor neurons. J Neurophysiol 69:2056-2071.

Haugland FN, Wu C-F (1990) A voltage-clamp analysis of gene-dosage effects of the shaker locus on larval muscle potassium currents in Drosophila. J Neurosci 10:1357-1371.

Henikoff S (1987) Unidirectional digestion with ExoIII in DNA sequence analysis. Methods Enzymol 155:156-165. 
Hevers W, Hardie RC (1995) Serotonin modulates the voltage dependence of delayed rectifier and shaker potassium channels in Drosophila photoreceptors. Neuron 14:845-856.

IIoger JII, Walter AE, Vance D, Yu L, Lester HA, Davidson N (1991) Modulation of a cloned mouse brain potassium channel. Neuron 6:227-236.

Hubbard CS, Ivatt RJ (1981) Synthesis and processing of asparaginelined oligosaccharides. Annu Rev Biochem 50:555-583.

Jan N, Jan LY, Dennis MJ (1977) Two mutants of synaptic transmission in Drosophila. Proc R Soc London [Biol] 198:87-108.

Kaang B-K, Pfaffinger PJ, Grant SGN, Kandel ER, Furukawa Y (1992) Overexpression of an Aplysia Shaker $\mathrm{K}^{+}$channel gene modifies the electrical properties and synaptic efficacy of identified Aplysia neurons. Proc Natl Acad Sci USA 89:1132-1137.

Kishimoto A, Nishiyama K, Nakanishi H, Uratsuji Y, Nomura H, Takeyama Y, Nishizuka Y (1985) Studies on the phosphorylation of myelin basic protein by protein kinase $C$ and adenosine $3^{\prime}: 5^{\prime}$-monophosphatedependent protein kinase. J Biol Chem 260:12492-12499.

Kornfeld R, Kornfeld S (1985) Assembly of asparagine-lined oligosaccharides. Annu Rev Biochem 54:631-664.

Kozak M (1989) The scanning model for translation: an update. J Cell Biol 108:229-241.

Krebs EG, Beavo JA (1979) Phosphorylation-dephosphorylation of enzymes. Annu Rev Biochem 48:923-959.

Kuenzel EA, Mulligan JA, Sommercorn J, Krebs EG (1987) Substrate specificity determinants for casein kinase II as deduced from studies with synthetic peptides. J Biol Chem 262:9136-9140.

Li M, Jan YN, Jan LY (1992) Specification of subunit assembly by the hydrophilic amino-terminal domain of the shaker potassium channel. Science 257:1225-1230.

Majumder K, DeBiasi M, Wang Z, Wible BA (1995) Molecular cloning and functional expression of a novel potassium channel beta-subunit from human atrium. FEBS Lett 361:13-16.

Morales MJ, Castellino RC, Crews AL, Rasmusson RL, Strauss HC (1995) A novel beta subunit increases rate of inactivation of specific voltage-gated potassium channel alpha subunits. J Biol Chem 270:6272-6277.

Mulloney B, Selverston AI (1974) Organization of the stomatogastric ganglion in the spiny lobster. III. Coordination of the two subsets of the gastric system. J Comp Physiol 91:53-78.

Nevins JR (1983) The pathway of eukaryotic mRNA formation. Annu Rev Biochem 52:441-466.

Padgett RA, Grabowski PJ, Konarska MM, Seiler S, Sharp PA (1986) Splicing of messenger RNA precursors. Annu Rev Biochem 55:1119-1150.

Pak MD, Baker K, Covarrubias M, Butler A, Ratcliffe A, Salkoff L (1991) $\mathrm{mShal}$, a subfamily of A-type $\mathrm{K}^{+}$channel cloned from mammalian brain. Proc Natl Acad Sci USA 88:4386-4390.

Papazian DM, Shao XM, Seoh S-A, Mock AF, Huang Y, Wainstock DH (1995) Electrostatic interactions of S4 voltage sensor in shaker $\mathrm{K}^{+}$ channel. Neuron 14:1293-1301.

Payvar F, Schimke RT (1979) Methylmercury hydroxide enhancement of translation of transcription of ovalbumin and conalbumin mRNAs. J Biol Chem 254:7636-7642.

Pfaffinger PJ, Furukawa Y, Zhao B, Dugan D, Kande ER (1991) Cloning and expression of an Aplysia $\mathrm{K}^{+}$channel and comparison with native $\Lambda$ plysia $\mathrm{K}^{+}$currents. J Neurosci 11:918-927.

Quattrocki EA, Marshall J, Kaczmarek LK (1994) A shab potassium channel contributes to action potential broadening in peptidergic neurons. Neuron 12:73-86.
Quick M, Naeve J, Davidson N, Lester HA (1992) Incubation with horse serum increases viability and decreases background GABA transport in Xenopus oocytes. Biotechniques 13:360-364.

Rettig J, Heinemann SH, Wunder F, Lorra C, Parcej DN, Dolly JO, Pongs $\mathrm{O}$ (1994) Inactivation properties of voltage-gated $\mathrm{K}^{+}$channels altered by presence of $\beta$-subunit. Nature 369:1637-1641.

Roberds SL, Tamkun MM (1991) Cloning and tissue-specific expression of five voltage-gated potassium channel cDNAs expressed in rat heart. Proc Natl Acad Sci USA 88:1798-1802.

Salkoff L, Wyman R (1981) Genetic modification of potassium channels in Drosophila Shaker mutants. Nature 293:228-230.

Sambrook J, Fritsch EF, Maniatis T (1989) Molecular cloning: a laboratory manual, 2nd Ed. New York: Cold Spring Harbor Laboratory.

Schwarz T, Papazian DM, Carretto RC, Jan YN, Jan LY (1990) Immunological characterization of potassium channel components from the Shaker locus and differential distribution of splicing variants in Drosophila. Neuron 2:119-127.

Selverston AI, Moulins M (1987) The crustaccan stomatogastric system. Berlin: Springer.

Shen NV, Chen X, Boyer MM, Pfaffinger PJ (1993) Deletion analysis of $\mathrm{K}^{+}$channel assembly. Neuron 11:67-76.

Singh S, Wu C-F (1989) Complete separation of four potassium currents in Drosophila. Neuron 2:1325-1329.

Solc CK, Aldrich RW (1988) Voltage-gated potassium channels in larval CNS of Drosophila. J Neurosci 8:2556-2570.

Solc CK, Zagotta WN, Aldrich RW (1987) Single-channel and genetic analyses reveal two distinct A-type potassium channels in Drosophila. Science 236:1094-1098.

Strong M, Chandy KG, Gutman GA (1993) Molecular evolution of voltage-sensitive ion channel genes: on the origins of electrical excitability. Mol Biol Evol 10:221-243.

Tanouye M, Ferrus A, Fujita S (1981) Abnormal action potentials associated with the Shaker complex locus of Drosophila. Neurobiology 78:6548-6552.

Tierney AJ, Harris-Warrick RM (1992) Physiological role of the transient potassium current in the pyloric circuit of the lobster stomatogastric ganglion. J Neurophysiol 67:599-609.

Tsunoda S, Salkoff L (1995a) Genetic analysis of Drosophila neurons: Shal, Shaw and Shab encode most embryonic potassium currents. J Neurosci 15:1741-1754.

Tsunoda S, Salkoff L (1995b) The major delayed rectifier in both Drosophila neurons and muscle is encoded by shab. J Neurosci 15:5209-5221.

Wei A, Covarrubias M, Butler A, Baker K, Pak M, Salkoff L (1990) K+ current diversity is produced by an extended gene family conserved in Drosophila and mouse. Science 248:599-603.

Wilson GF, Kaczmarek LK (1993) Mode switching of a voltage-gated cation channel is mediated by a protein kinase A-regulated tyrosine phosphate. Nature 366:433-438.

Woodgett JR, Gould KL, Hunter T (1986) Substrate specificity of protein kinase C: use of synthetic peptides corresponding to physiological sites as probes for substrate recognition requirements. Eur J Biochem 161:177-184.

Wu C-F, Haugland FN (1985) Voltage clamp analysis of membrane currents in larval muscle fibers of Drosophila: alteration of potassium currents in shaker mutants. J Neurosci 5:2626-2640.

Zagotta WN, Brainard MS, Aldrich RW (1988) Single-channel analysis of four distinct classes of potassium channels in Drosophila muscle. J Neurosci 8:4765-4779.

Zhong Y, Wu C-F (1993) Modulation of different potassium currents in Drosophila: a hypothetical role for the EAG subunit in multimeric $\mathrm{K}^{+}$ channels. J Neurosci 13:4669-4677. 